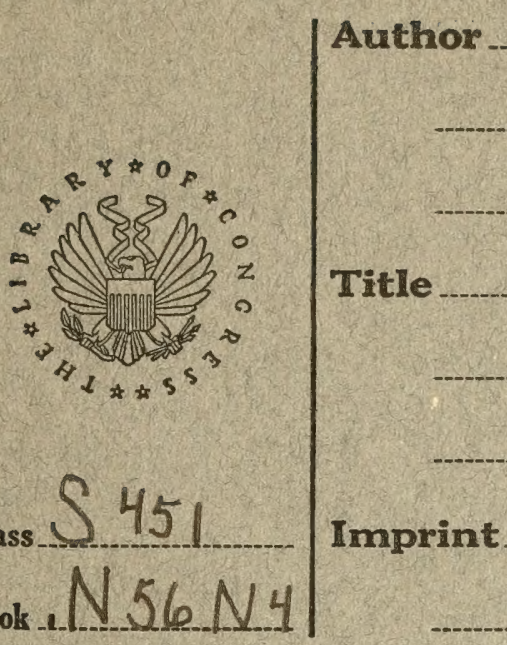



AN EXAMINATION

INTO THE

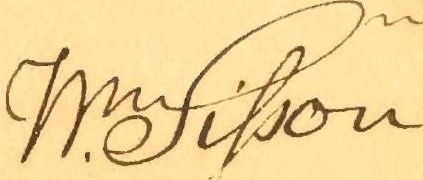

EXPEDIEN

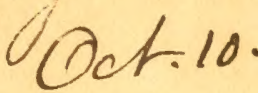

\section{BOARD OF AGPICULTURE}

IN THE

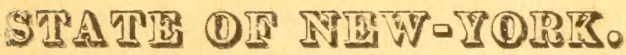

PUBIISUFD BY TIIE

PEW-TORK CORRESPONDING ASSOCIATION

FOR THE PROMOTION OF

INTERNAL IMPROVEMENT'S.

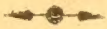

*. WORTHגNGTON, PRINTER, EROOKLYN.

1819. 
IHE

NEW-YORK CORRESPONDING ASSOCIATION FOR THE PROMOTION OF

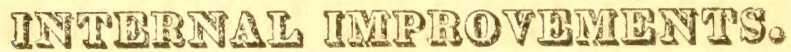

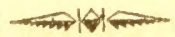

OFFICERS OF THE ASSOCIATION:

DE WIT'T CLINTON, President. $\left.\begin{array}{l}\text { SAMUEL L. MITCHILL, } \\ \text { CADWALLADER D. COLDEN, }\end{array}\right\}$ Vice-Pres'ls.

COMMITTEE OF CORRESPONDENCE AND PUBLICATION.

THOMAS EDDY, Chairman.

William Bayard, Tueodores Batey,

Stluands Millek, James Tallmade, Jun. Robert Bogargus, HoNkY POS'T, Jun, Treasurer.
Pierie C. Van Wyck, John Pintakd, James I. Beli, John MCKesson, R. H. Bown E.

\section{CHARLAS G. HAINES, Corresponding Secretcry.}




\section{AN EXAMINATION, dc.}

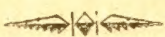

AS the establishment of a Board of Agricunture, is re. commended by the Executive to the Legislature of the state of New-York, it may not be unprofitable to take some view of the deep inferests dependant upon its institution, and the salutary effects which it would produce.

Agriculture, like other leading branches of industry, embraced in the seience of political economy, is daily becoming a subject of greater moment in our country. As the great fundamental source of human subsistence, as the imperishable basis of the wealth, power and grandeur of nations, as the support of commerce, manufactures, and the arts, it will now, we trust, receive the munificent and unwavering patronage that comports with the magnitude of its interests.

By some, it may be deemed ostentations, at a period like this, aud in a community so enlightened as our own, to quote the observations and opinions of illustrious writers, to confirm and fortify established truths, or truths that are embraced and sanetioned by a general belief But axioms in political economy, like those in the science of polities, which constitute the foundation of a people's freedom, may always be recalled with a salutary effect, when treating of subjects which are intimately interworen with their correctness.

"Land, (says a distinguished writer) is the true source of national wealth, besause it produces every thing that a man- 
desires for the suy ly of his wants, his enjoyments, his plear sures, and his fancies ; und because it constantly reproduces a quantity superior to what has been consumed, to effect its reproduction. This excess of reproduction, this gratuitous giit of the soil, this net produce, is the surest fund that ean be employed to encourage the proggress of labor, to rewart its sucess, to promote improvements, and indefinitely to increase the somree of public and private wealth,"*

"Of all arts (sags Vartel.) Agriculture is the most useful and necessary. It is the nursing mother of the state. The cultivation of the earth, causes it to produce an infinite in. erease. It forms the surest resource and the nost solid fund of riches and comaree, for the people who enjoy is happy climate"'

"Agriculture claims a pre-eminenee above marufactures and conmeree, fiom its security and superior usefulness. Mannfiatures and commeree originally owed their existence to agriculture, and the people employed in carrying them on, must constantly be fed by those who are engaged in the parent art. Agriculture may therefore be considered as of the first importance to mankind; besaust their temporal welfare and prosperity depend upon receiving a begular and sufficient supply of the various articles sultivated by the agriculturist. The territury possessed by any people, is the original property or eapital stock foom which they are supphind, not only with the neressaries, but also with the comforts of life; and in direet proportion as their territory is improved, their prosperity will be adrancell."

"It is not the number of people, but their wealth, which constitutes their power; and that population ought to bo sebovibate 10 agvienisure, so that the abundance of produes slouid constantly precte the increase of population."

* Ganith's Polit. Econ. 63.

+ Vattel's Laws Nat. ch. 7, p. 58,

t Edinburgh Eneyclo. art. Agricul.

Sir Adthur Young's lolitical Aritho 
4. Agrieulture, (says Mr. Malthus) is not only that species of industry which is chielly requisite to the subsistence of multitudes, hut it is in fact, the sole species by which maltitudes can exist; and all the numerous arts and manufactures of the modern world, by which such numbers appear to be supported, have no tendency whatever to increase population, except as far as they tend to increase the quantity and facilitate the distribution of the products of Agriculure."**

'These references to eminent political writers, are sufficient to show in what distinguished estimation they viewed the interests of agriculture. 'The Duke of Sully, whose bare name is the talisman that calls up every thing illustrious and great in the government of an enpire, called " Agriculture and Pasture, the two great breasts of nature, from which nations received their nourishment." The sagacious and philosophic Hume, has paid it a splendid homage, and Vattel, whom we have quoted, dwells upon the importance of rendering agricultural pursuits honorable in a state. He alludes to China, where once in every year, the Emperor holds the plough with his own hands; and he might have mentioned Persia, where on a festival, which was annually celebrated in honor of the art, the Persian king formerly addressed the husbandmen in the following language : . I au one of you. My subsistence and that of my people, rests on lise labor of your hands; the succession of the race of man depends on the plough, and without you we cannot exist. Our dependance is reciprocal-let us live as brothers, in perpetual hamony."

We are not, however, here ascrihing to agriculture, all those exchase attributes which are represented as his peculiar property by the agrieultural sect of political economists ; we are not entering into those conflices of opinion, which have exereised the ingenuity and called forth the eloquent

* Malthus on Population, vol. 1, p. 275. 
reasonings of the French, Italian and English economists, in diseussing the posion, that the labor bestowed on the soil is the only produetive labor. But we may assert with assurance, litat agriculture sustains the prosperity, power, and happiness of nations, on a foudation more permanent, more immoreable, more unfailing, than any ofhel source of industry embraced in the compass of human ingenuty or human improvement. The roal intrinsic sirength, riches, and independence of a state, mast be conacted with, and depend upon, the cultivation of its soil. Here is the invinrible bulwatk that batles the restraints, the edicts, and the proseriptions of a hostile world. Here is the frowning rampart, behind which a people may rest with seeurity, and tind internal peace and plenty, ahhough the nenacing doud of destuction, from external hostility, hang upon their bordes's. While the history of commerrial states, where they have been strictly of that clametro, has been marked by vicissitude, and a perpetual exposure to the restrictions, wafrice and enaity of loreign powers, even during the most brilliant eras of their maritime gieatness-that of nations resting their dependence on agriculumal resources, has been uniform as the revolutions of the seasons, and exempt from the effects of foreign animosity as the foumbation of their sail itself.

Neicher are we for encouraging agricullure at the expense of commerce and manufactures. The distinctions drawn betwen them by many public writers, can never apply to b. In our country, these three branches of industry, weallh and power, are allied to, and sustain each other by reciprocal patronage. We are a great exporting country. Our fertile and extensive soil gives us a vast strplus produce; our manufactories, by converting the abundance of the raw materials which we possess, into articles of luxury and convenience, will cnable us to withdraw our dependance on foreign supplies, and have an excess of manufactured produets, that will give us an ability of competing with ofles manufacturing nations, in forcign marbets; and commerce 
will convey the surplus fruits of our industry, both in agrio eulture and manufactures, to the various parts of the commercial world. In fact, nature has destined, that in the $\mathbf{U}$ nited States, agriculture, commerce and manufactures, should flourish in unison, and be bound rogether by indissoluble ties.

In our country, speaking in a national point of view, we have as yet mad but feeble and partial efforts in agrieultural improvements. As a science of an elevated and profound nature, it has not received that deep thought, and persevering and extensive encouragement, which it richly merits, and will, ere long, reeeive. Many causes explain this deficiency in the applieation of our ingenuity and resonrees. We have a country that is fruitful, and extensive almost beyond example, possessing a widely diffused population, furnishing but a few eulivators in proportion to the magnitude of our territory. Thus a single cultivator will find his labors more abundantly rewarded than one in England, or any other part of Europe, because he bestows his industry on four times the extent of ground, and on a soil, in many cases, more rich and exuberant. Our exportations too, which have been the basis of our direet commerce, lave not been of a deseription to lead our inquiries into the details of agricultural knowledge. Among our staple articles of exportation, have been cotton, tobacco, rice and indigo, whose eultivation has been confined to the planters of the south, and not a subject of general encuiry among the larming interests of the nation. The lumber trade of the eastern states, as well as their devotion to the fisheries, has had no connection with the perfection of this art. Our commerce bas dene little to advance a seientifie system of experiments and investigation in this respect. Our vast exportation of flour, our exportation of grain, live stock, beef, pork, butter, cheese, \&e. has, it is true, in some measure alvanced onr knowledge; but our entire exemption from want, and the natural fertility of our soil, has co-ojerated as an inducement to suffer our agricultural affairs to progress in their own naturial course. 
We shall show in the sequel a natural and necessary change in these important concerns. We must, also recollect, that our commerce has been of two kinds, and that one descripdion has not been immediately connected with the cultivation and disposal of our own products-we mean the carrying srade. During the wars on the continent of Europe, it is well known, that this branch of commerce became a vast source. of profit to the United States. and a souree that had no dependence on the cultivation of our soil. 'This trade fill with the belligerent system of the warring powers. Another cause, which operates with no inconsiderable efrect, is the distinction between the ayricultural classes in this country and those of the first agricuitural nations in Europe. In England, and in other quarters of the old continent. the soil is in the hands of great landholder's, the lords of the domain, possessing immense wealth, and frequently great revenues, independent of the proceds of their real estates, and every way able to make expensive experiments and expend large sums of moncy, and bring their lands to a high state of agricultural improvement. This has been the case in England and France. Necessity too, from pancity of territory and density of population, has also added some stimulus to invention. We wish not for this condition of things in our own country ; we only say, that it has only tended to elevate agrieultural knowledge in many parts of Europe to the highest standard of perfiction and to which we can easily attain, without feeling the pressure of an odlious disparity in civil enjoyments and eivil rights. In our country, professional devotion. and commercial pursuits, embrace a great proportion of our enterprizing and wealthy population. 'The cultivation of the soil, especially in the northern, middle and western states, is generally left to that intelligent and respectable portion of eommunity, whose afluence gives them independence, but not the means ant opportunity of devoting time and expense to the aequisition of knowledge hy research and experiment, in order to extend the sphere of practical knowledge. Habits and pre- 


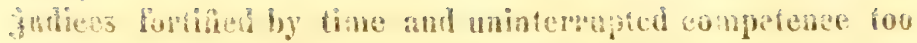
othen shut out the light of hatelligeace, when it wears the asfreec of novely. And in fact, to comblute on this poinh, our sountiy is still goung, in sational existenes, and of course,

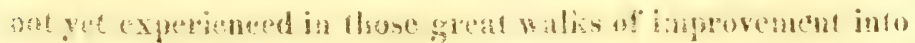
which we are now entering. for a hang and tramphant conser. It is with nations as with hidlividuals; time is esseatial to the consummation of excellenee and weatness.

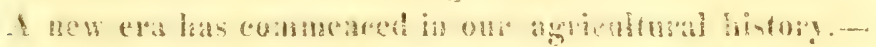
"The present year presents us with immovenents that gute a

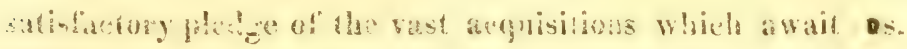
The first states, ats well as the first statesmen, in our aion,

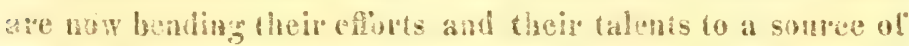
ntational power and grealness, that will repay their exerions

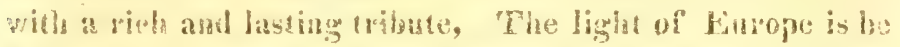

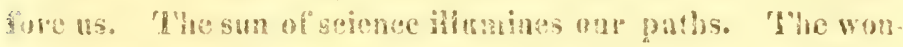

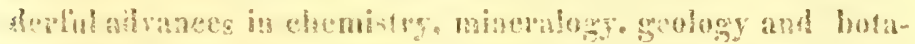

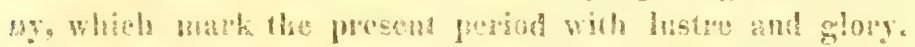

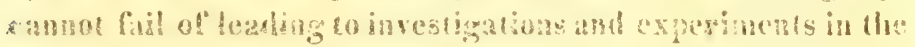

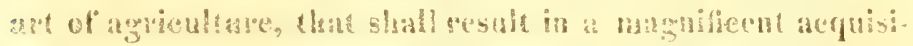
fion to the are in whids we live, ant at benche of the derpest

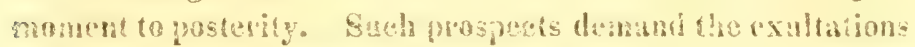

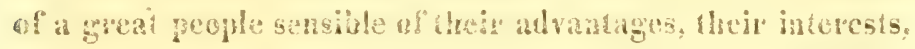
and their future fisme.

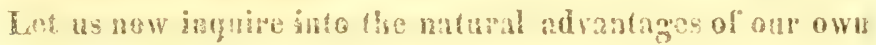
state for agrieulumal imporement.

In roncupdating the physical ant mond adratages of

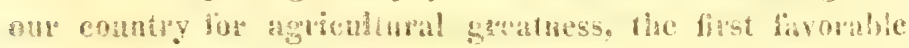

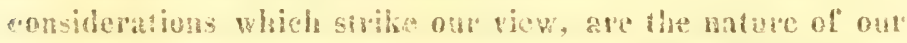
free and bitseral ingtitutions, the tegon of our landed propery,

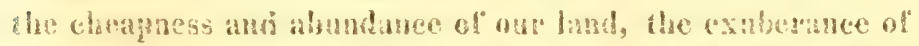

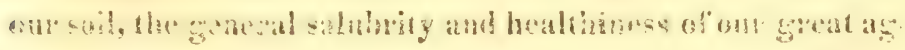

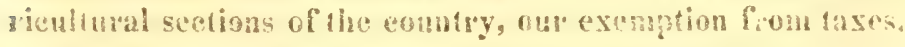
and the frectent of our commerec. In nany resperets, a that fering confust arises as we compace oun comber with the

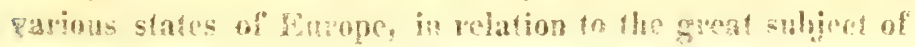


which we are treating. Fine feudal system of the easieg continent has left the stem inpress of its fratures on the porliteal intilutions which have followed its disolutina. It

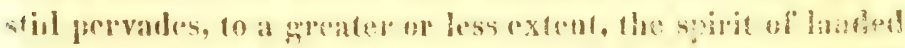

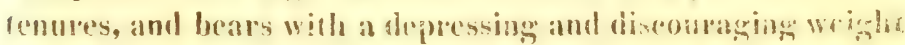
on the cultivators of the soil. 'Whe manner of setting contravts, the duration of leases, the covenants to be inserted. the form. and every thing conaceled with them, is an imser tant part of the angiculural colle. 'To every one, it must he apparent, that a system of lanted tenures, that opprenses

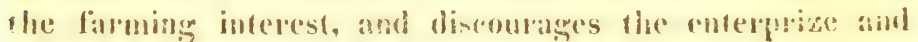
hackles the energies of the cultivatos, must be highly projurleial in impeding the nuweh of imporement. 'The taxes, too, of liurope, in the shape of tythes exactions, exe. to stestain the prodignacy of governments; the vast proportion of unprobetive propulation who live on the babrs of the inferior classes; the immense enolosures, parks, and pleasurs grounds, devoted en the bille amusements of the nobility are st many deawbacks on the apereral prosperity of ayriculture in the old world. If tirese burdens, operate in favor of a high state of agricultural improvement in producing. by the cocrecion of neecsuity, the most atterative cultivation of llae soil; they constitute a liset that only goes lo shew, to what extent the same and may he carvind unler a government, and under cireumstances, congeniad to the happiest interests of mankind.

In the Cuited States, we have a government that is mild,

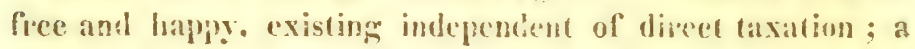
elimate that embraces all the physieal blessings which distinguish the most benejient quaters of the world; a terrirory that possesses all the varions soils of the ghobe, producing every matcrial prociuclion that can be foumb in the confines of Europe, and nany reppical flanis that Lurope rannot furnis!. We are daily beconing mone and nore the stanary of the world ; and whatever strerior aefuistions of hnowledge are possessed in kinropre connected with the 


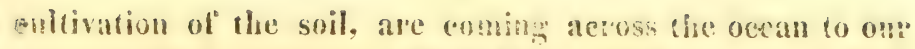

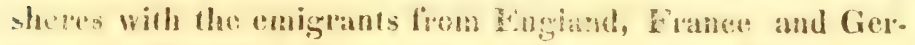
many, and every other sertion of the continent.**

Wibh these general remarks, let us turn to the state of Tow- Yosk. But few countries of" the same magnitude, piesent az exeater variety and extent of natural resources.

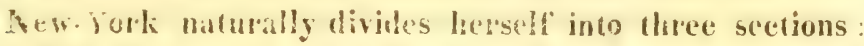
the flib is comprehended by the soil on the seaboard, and lying ras of the nountaits. which, wth broken ridges, exremes theolith our state: the sceoth may be ealled the mounpaineus desidet, comprising that portion of our state which is whe least value, and whith divides the scaboad and the lamis a!z ibe east of the rifige of mountains, from the territory of the west ; the thisd is that vast and firtile country whisto lises hito an cherated plain, embracing in its bounda. ries the shores of the St. Lawrenee, the borders of Lake Gutario, and part of Latie Five, die nothern limits of P'enusylvania, and the nourees of the Molawk. 'The eastern division, is in genetul a rich and productive country, possessing a soil that is warm, dig, ath prolifice. Some of the rountiu's in this section, are turler a bigher state of cultivapion thas any other portion of our state. 'She alluvial flats ale absondanty exuberant, and buing forib an inerease that places their lertility in competition with any tarets of rombtry in Euroire. As we progress to the mortin, the soil is not so firolable, cxhibiting a difilerence of elimate and productions. 'This part of unt state is hom erer capable of a high culdivation wilh a fen exceptions, and is datly improving by the enterprize and perseverance of a hardy and valuable

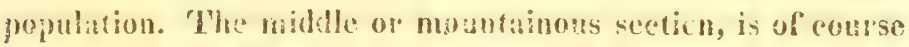
more diversitied and broken than the castern or western. containing the greatest quantity of unpoluctive lands. The valies ate howerer rich and valuable, the more elevated parts

* Vide Speech of Le Ray de Chamonto and the Leters of 31. Bir!ject. 


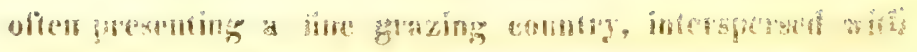

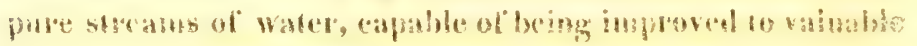

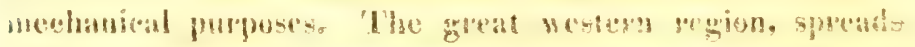

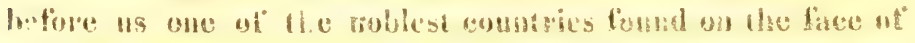

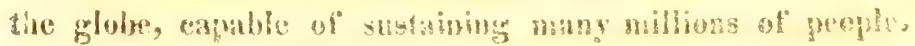

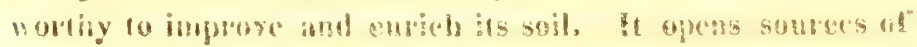

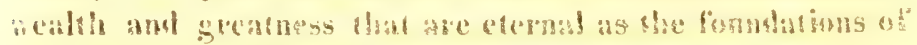

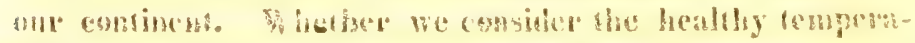

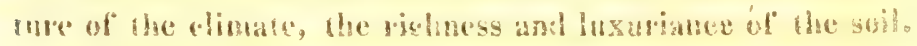

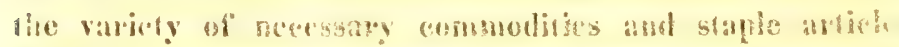

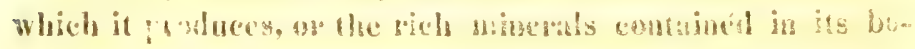

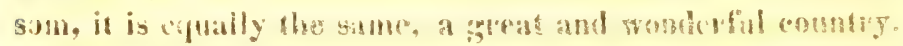

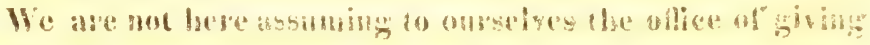

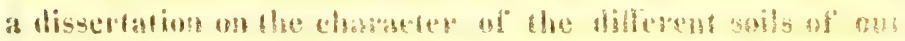

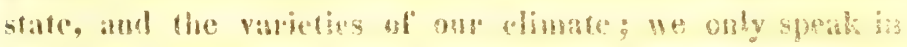

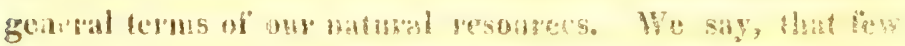
triburies of the same cxtent present sn little waste labsh, and

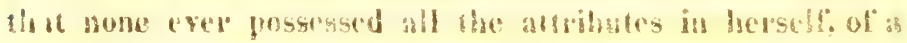

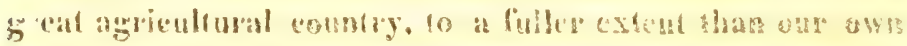

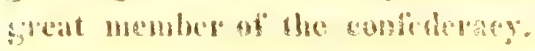

Alopting the thery as correct, that the bithess of the soit

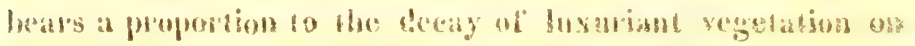

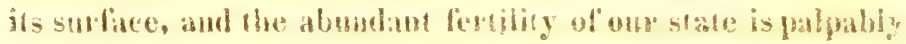

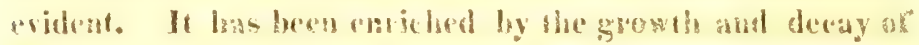

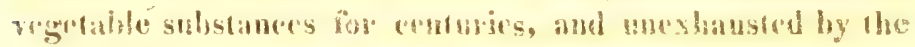

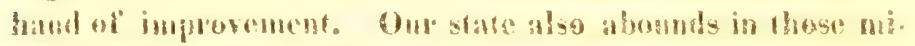

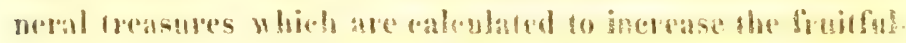

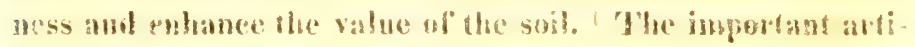

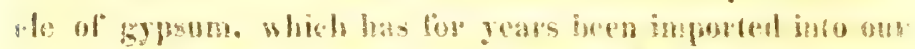

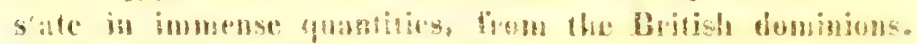
bas ben discovered in the heant of mon nestern district, in

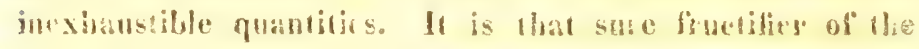
swit, that in every pabt of om extended territory, excepting

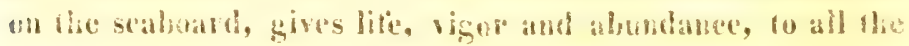

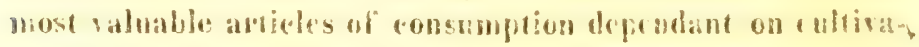

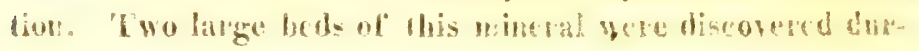




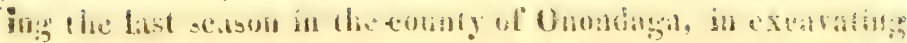
the route of the Great bestern Canal, and ean he allonded in any part of our state, at from three to hive dollats gen son. Whe rich matl found in gresed abundance at the west, has also been groved to be of much utity in promoting the growh and abundance of vespetation.

Next to a tertile soil and a healthy chmate, conveniem, a'gular, and profitable markets for the disposid of suphlus fleduce, naturally come under conshleration. In this respect,

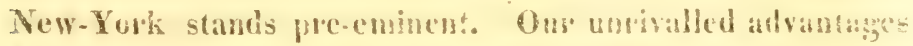
for commerce and internal conveyone? the imporentoms now making by our state governmem, on a stith bate edipses all the enterprize of Europe fob the last eratur? gives the assmanee of a system of inland communcation by

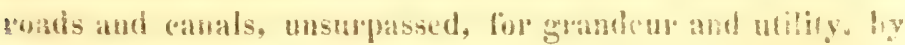
any councry in the universe. The union of the lubison an bake Champlain, hy the nombers eanal, fortas a gevat and never firiting ehamel from nouth to south; the westem

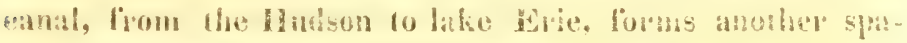

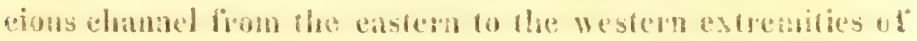
our state. 'l'athing into view, lhe tributary streants which

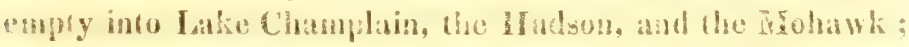
the rivers, erestis, and smatl lakes, which will be united (1) the line of the western canal; tahihg into vien, alse. the canal which can eastig unte the behawate niver fo the mouth of the Ilutson, which the incerests of tho states cie. mathd and besides all this, the munerous routs fhat with intersect the two great, as well as the small ebumbls ob conveyanea, and we may safely chathene the fice of cacation, and lise wide compass of human discovery, 10 produce a gander sapetacte of all that is eminently favorable in inland wade. flere, then, will agrienture find an encomage-

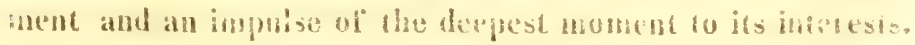
Gresy suphtus product wiil thed a safe, chop, and ablit

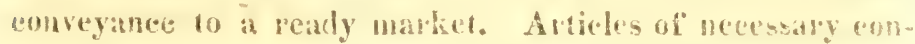

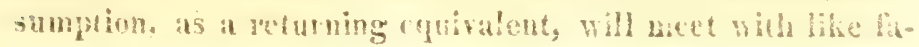




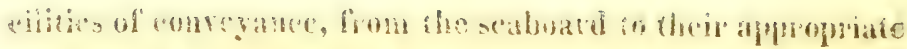

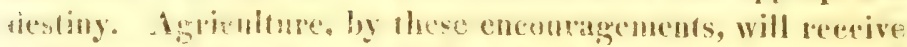
at lifis and vigne diate will depend wa no incidental state of shings, but a liti and vigror lasting ats the physieal constirn. don of our hills and our vallies.

What linits are, leveafter, 10 bound our agricultural en terphize and greatness, we shall not venture to say ; but let us for a monent indulge in compurison, the only methou ta abuertain the mognitude of ohjects. Let us cast our eyes

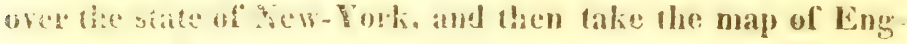

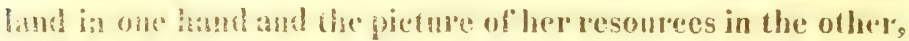
and ponder on the extent of her agricultural riches. Surniand is a cotniry possessing less natural advantages than ont owa state. Holuding Wales, G. Britain contains $\$ 9,000$ salate milos, mahing !ot far from $31,000,000$ of acres. NewYork contans be, 000 square miles making over $29,000,000$ of acres. bischand has more waste bands than the state of New-

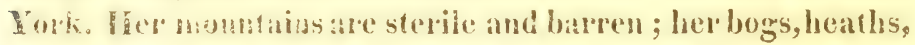
and chatly lands, as well ats her large racts of loose spongy growahe are not known as charateristies in our soil. Her chmate possesses few or no advantages over our own. 'The

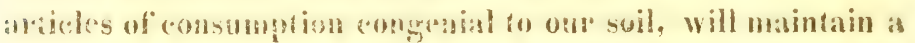

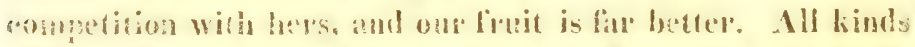

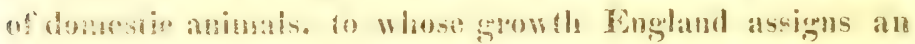
ingontant palt of hel veald, subsist as well here as in Great Bhitain. * Se must, also, reculleet that the parks, com-

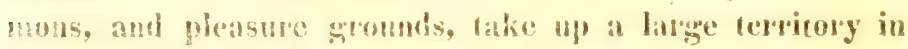
songland; that her fromes are burdensome, her taxes monstrons, her esports shathled, her cultivators oppressed, and

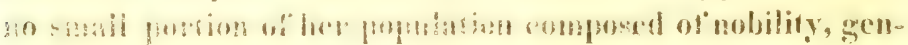
thaten, professional men, soldiers, placemen, sinecurists,

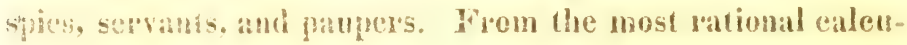

* 'The whole number of" slecep in this state was estimated at

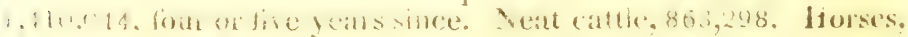
$527,5 \pi 0$-argoregate, 2,850,952. Whe number now is much

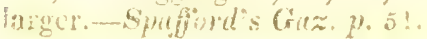


bations. the cultivatos of the soil fall considerably shon of fwo millions in England and Wales.* Yet, und:r all these? eircumstantes, what hat Englansi done as an agricultural nation?

An eminent Eaglish witer, cqually distingublod for his cambor and abilities, has estimated hat the weabh which is annualiy cereated by the euttivation of the soil of (iveat. Britain and breland, amounts to no less than f216.987,62i. Ife gives lectand two-fiftis of this amount, which, when deducted from the whole estimate, leaves an anmual creation of wealth from the soil of England and Wales alone, the enormous amotint of $\pm 150.090 .5 \%$, or S575.550,828. Ifere then is nealy SR MUNBRED MHLIONS OF DoLLARs, annua!ly wrung from the British soil, possessing inficrion allobutes and properties to the soil of NewYork! The able book cntitied “ Britain Independant of Commeree," estimates the amual caration of property in EngLand, by means of agricul(ure, to be $£ 120,000,000$; but the estimates of Mr. Colqulioun are obtained frotim more aceurate somecs, and more correct. Ken freland grives an amual ereation of wealth from the cultivation of her soil to the amount of $\$ 355,55,218$, if we talie the enteulations of the above author as a lata. England and Ireland focther moduce an ansual weath fou the cultivation of the soil of the amount of \$961,136,5ik. And get Englaml did little or n9thing for her agriculture and rubal economy until the time of Queen Elizabeh ; and in fact, never brought this branch of industry to any general perliction, until the establishuent of her Board of Agriculture.

* From the result of the population act, it appears, that of the 8,300,000 persons, which England then contained, only 1,524,000 were chichy employed in agriculture; so that of the 12,000,000 which Great Britain, including Wales, is supposed to contain now, there camot be imputed to be more than one-sixth part smployed in cultivating the arth.- Fide Britain Independent of Commerce, p. 47.

tColquhoun's Wealth, Power and Resources of the Britisls Empire. 
We are not puttim the present agricultural besoures of the state of Pew-Yoth by the sibe of those of Great listain. Whe are anly sngestinge by lay of comparison, what New-

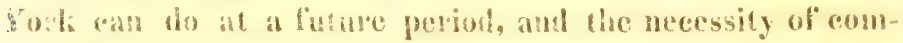
mencing hes career of improvement on a greal seale, at the present moment. Wo must recollect, that while the populatim of England loes not double onee in 100 years. ours cloubles ouce in 20 year's. Liut a few rears more, and we shall have as much eficetive lopee employed in the culiiration of our lands as Lingland now has, and the fanits of our labor will not be devoured by tax-gatherers-exeise oficers-a profligate, ible nobility - inies_subsitles-sinecurists-ylacemen-servats-and paupess : but they will go to enroh a great and enterprising community. With ald ous pride and love of national greatuess, we cannot realize the gesources of our country of of our state. 'Rhey unliold unseen, and astonish us, at limes, with tiseir womberin! devel. opement. The tonatge of New- lork is now far yreater than

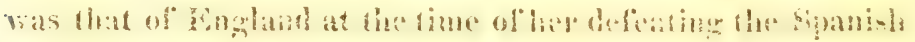
armata, when Spanio was mistress of the oeran-and ever symerer than that of Lugland one century ago. If a stirte would be great, she must elevate her looughts to the stanthat of greatmes, and het her cionts compon with her views and conceptions.

We shall now consider what bratabes of knowledge are. connected with agericulture, as a seience.

There is an aparent simplicity in Agrumbur pursubs

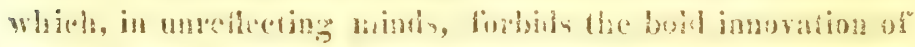
cxperimental improvements. Such has beea the benefoconee

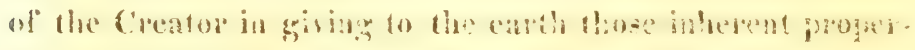
ties which sustain the human rate, that we ahost forgut the necssity of improsing those lownties to the full ratent to which they are capable of being enjoyed. 'Thus the man of

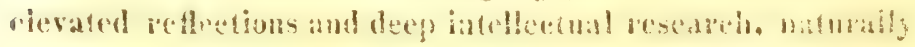

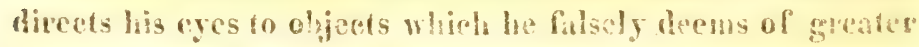
importance to mankint: white the enhivator of the suil 
the giss not to bow to the shrine of scienee and philosophy, Shat he may borrow lipht and knowledge to irraliate the where of his useful exertions. The last few years, however. Bave produced a great and salutary revolution in these opinbons. Whe most abstruse sebenes have been applied to the modinary pursuits of industry, and hought bome to all the ronvenichees of life, and the happy tendeney and infuence have been filly soen and acknowledged.

In making agrieultural improvements, it is requisite to have sn aceurate lnowedge of the climate of the country, and an intuate acquaintance with the effects which its changes and vicissitudes have on different hinds of soil, and efifterent speeies of vegetation, and a knowlerige of all the vegetable productions eongenial to its nature. In considering the climste of a country, in relation to agriculure, an cmionent Enghish writer embraces the following points:- Its general chatraceres, and the lateans of its improvement-its heat -l'he quantity of its moisture-The prevaiting winds-ats

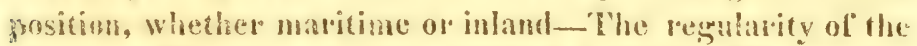
seasons-The phemonana to wheh it is lisble-The producvions lnest strited to it-The introduction of exotic plants and animals foun other chmates, Fene then it becomes neeessary to kuow the propertics of what some writers on agri. conture call the acrial kinglom, and also to possess an intimate acquaintance with the vegetable kingdom.

A knowledge of the suil with all its diflerent hitrinsic virques, is next to be considered. The writer before alluded to. has divided soil into seven kinds-sand, gylavel. clay, chalk, grat, alluvial, and loam, the artilicial soil created by working the ocher soils. It is reguisite to undersiand the nature of ail these different soils, the extent to which they are mixed wr partake of each other in many eases, the sub-seils or unalele stratums on which they rest, and the different producions whish are suitabit to their nature and constitution. 
The cultiration of the soil comes next in view. This in.

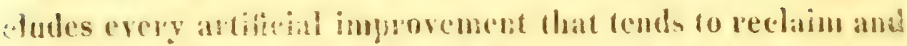
promote the fertiligy and value of lands, and lheir conversion to that condition of texhme and comistence that will most farophly atranec the sowols of all hinds of valuable vege-

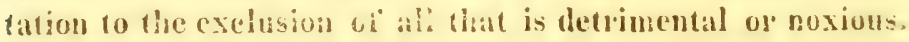
It is reguisite for she cuhtivator to understand the nature and strength of difiereth linds of manures, the proper degrees or extent of theis applitation, what kinds of agriculmua? produats are suitable to various soils, and how their growli

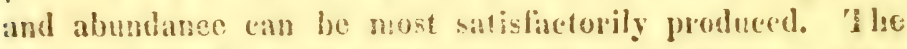
managenent of arable and grass lands alone, onitling ever! thing clse in the economy of myriculture, presents an im. mense ficli for experiment, ingenuty, and invention. Dr. Rees, in his valuable article on agriculture, instances the following bramehes as belonging to the improvenent of arable and giass lands.

The inclosing and maling of fences, as hedges, ditches, walls, railings, palings, gates, draining, paring and burning. watering, waphing, fallowing, ploughing, manuring, sowing. harrowing, weeding, hocing; the grou ing and preserving of diflerent sorts of erops. as wheat, rye, barley, oats, beans, peas, potatoes, tumips, carrots, cabluges, hops, hemp, flax. woad, malder, de.; and the raising of varous kinds of seeds, as rane, mustatd, ke.; zotation of crops, rewping, mow ing, stacking, thrashing; ; the management of artificial and natural grasses, as doter, luecrn, saintloin. lares, veteltcs, de. : the converting of arable lands 10 grass, meatows. pastures, hay-making; the cultivating and preserving of fruits, as apples. pears, cherries, de.; and the prepanation of fruit liquors. as civer, perry. Ece : orthards; the planting of timber-trees, woods, coppices, plantations, $\delta$ c.

The management of frut and the culivation of frableces is daily becoming of nore importance in this country. It $\mathrm{i}$. orident that many foreign fruits found in varous parts of the gitule, will bear trasplanting into on! soil. ant preduer the 
bonnties with all the vigor and alsundance incident to theis native regions, The cultivation of fruit trees alone presents an intrieate and important seience, and a seience that is doubly necessary to be known in our country, considering our re. eent existence, the newness of our luth!s, the ease with which we can ritise foreign fruits, ont want of experience, and the rast field for improvement which is before us.

The importation of diflerent spories of grain, and, in fact. the procuring of all kinds of seeds from foreign regious to prove lieir fidvorable or unfavorable adoption in our country, is decply important and necessary at the present stage of ous agrieultural history. We have not yet applied the serutinizing toteh of experiment, in this respect, to that extent which which our prosperity demands. Some regular and persevelsng system of correspondene with distant quarters of th: lobe is requisite at this periot.

The rearing of live stock in agrifoultural countries is an object of the first consequence, and considered worthy of attainments in knowledge that can only be acquired by a long, constant, and philosophical attention. In England as well as in various otler countries of Euroje, the improvements in different breeds of eattle, horses, sheep, and other domestic animals, has engrossed the watchful patronage and consideration of eminent and seientilie men, and demands the same, and even greater weight here, because our country, in this respect, has done but litte in comparison to her means and alvantages. The species of live stock best adapted to different sections of the country; the means of improving them hy erossing the houd, atministering nutriment, and otherwise; the food most genial to their growth and constitution: the economical expenditure of nourishment; * the difierent

* The amount of fond consumed by live stock in Englant? strongly presents the magnitude of the subject. The quantity of wheat, barley, oats, ryc, beans, and peas, consumed by man, in Freat Britain, has been estimated at 18,750,000 quarters; by nimals, at $11,899,009$ quarters. The unmber of horses in Great 
habits of anmats, with a knowledge of hien discands ant whe jroper application for their remedy and enre-these numuerous points present us with olyjects of 100 much conse-. afuence and import to be left to the sport of time, aceident. snd inattention $f$

The implements of husbandry, in the cultivation of thic soil, stribly pertain to agriculdural improvements. Propes tools in tillage diminisis expense, save hbor, and cnable the farmer to vest a spreater portion of his eapial in his rumbl oceupations. Where is a giveat deficiency in this respect in many parts of the United States. Our implements are he aivy, awliwatl, and unvicldy, consuming in their use an im.

Britain and Ireland is estimated at 1,800,000; homed cattic, $10,000,000$; sheep and lambs, 42,000,000; all of them consumjug hay, grass, staw, retehes, turmips, carots, and grain to the smount of $\mathcal{E}^{\prime} 103,400,000$.

\section{[Culquhoun's Resources Brit. Emp.}

t The following extract from a London paper slsews the en. couragement to raising excellent cattle:

"The following extraordinary sale of stock of the improved short-horned breed, took place at the sale of Mr. Rohert Colling, of Barmpton, near Darlington, who has long been celebrated as an: agriculturist of the first class, and whose stock was brought to the hammer on the 29th and 30 th of August:
One 2 year old cow, sold for 331 guincas.
One 4 year old cow, do. 300 do.
One 5 year old cow, do. 370 do.
One I year old bull calf, do. 270 do.
One 4 year old bull,
to. $621^{\text {\% }}$ slo. that

And it appears by the catalogue with printed prices anixerl. $\$ 34,91286$.
34 cows
17 heilers
sold for
6 bulls
do.
4141 guineas.
4. bull calves
do.
1287 do.
1343 do.
713 do.
$\overline{61}$ head of cattle sold for, total, 7484 guineas-ar

['The above cattie are of the breed of the imnorted bon! exh. vited at brighton, Mass in October last. $]$ 
meinse lalsol of hoses, oxen, and men. These are evils which our chatanteristic mechanical ingenuity could easily remedy, with proper attenton an! encouragencent. 'The Code of Agriculture classes implements of husbandry under. the following heads-1, Implements of 'Tillage; $\leadsto$, for Drilling or Sowing Corn ; 3, for Reaping Corn ; 4. for In vesting Corn; s, for "I hreshing and Cleaning Corn ; 6, for Nowing and IIarvesting Hay ; 7, for Convey anee and liwas portation; 8, for l) maining; ; for Marnessing Stock ; 10. for Rulling Land; 11, for Dary ; and 12. for various Blis. eellaneous purposes-p. 66. 'The inventions and impruve. ments to be made in this departunent reguire no ordinary in. şenuily and expense.

IIere then is a slight view of what mertains to agrieuiture in this and other countries.

Roads and canals have been viewed as important feature. in the agricultural systems of Europe. Railways, harbours, combankments, and out-buildings sate also considered as consti buent parts of the same great plan to promote the means of sustaining mations through the cultivation of the earth Roads and canals are certainly of rast impotance in bring ing good markets, virtually, to the very boors of the farmer, and opening new and easy sources of diffusion to all the pro. suctions of the soil. In the state of Nen-York, this truth is duly estinated, and under the wise and liberal guidance of sur present state government, will be fully realized: in a nar fional point of view, we have made 10 great movements to this end.

On what, then, does the science of agriculure rest? Is st infleed an humble art, confined to a sphere blat is depres. sed and condracted, and ouly to be improved by hose who turn the glebe, seatter the seed, and reap the harvest? Does sot the science of agriculture, even in the luicf and partial -iew which we have taken of it, rest its foundation on a knowledge of natural philosoplay, so fur' as to decide on the nature and changes of climate. a lnev ledge of ninepalog. 


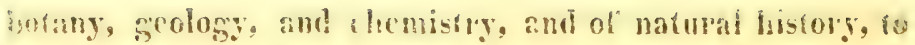
the batitude that the raring and nonsistment of live stock is involsed ; and may ne not eren include the mechuneal arts, iin as much as thry are connceted with labor-saving implements of husbandry, and other external improvements? And will it be pretended by the considerate, the liberal and reflecting partion of communily, latal agriculture, whose sue-

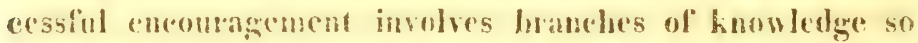
decp and intricate, should be left to make its own progress 10 pipfection. as timat, aceident, and ignorance shall dictate? shall fle fundamental and vial art that sustains all others, he hathe deformed vietim of habit, penury, and prejuliee? We ledieve, nay, we linow, that there is a prous and enter. mising spirit in our "ommunity, and among our farming inte: cst too, that brands with indelible marks of denunciation, such a supposition as lihs. Our agriculture must, and will seceive, in the state of New-York, the solid and growing pa. tromage of an intchigent people, and a wise and energetic goverinment.

I'o say that agrieulture does not need the cxtraneous aids which seienee can extend-10 maintain that it wants not the light of those experiments and surgestions, which are the in. vahuble offopming of grent men's lesearches and reflections, is paying a degrading tribute to the triumph of ignorance, and weaving garlands around the brows of stupidity. It $i$; discarding common sense and extinguishing the light of truth, whon snch atets blast the interests of communities and states, and cast a disgracetul blot on the hustre of the age. "Leare the formers lo llemseltes," is a common remarli, and it is a remats that is lhancteristic of a cold heart, a penurious spinit. and a weak mind. It would as well apply to all the certupations that engross the labors of mankind, as to the art of' tillage. 'To whom are we indebted for those philosophi"al improvements which are applieable to domestic purposes, anl extend, to an immeasurable degree, the blessings of existenee? Who invented the compass which direets the shig: 
through unknown seas? was it the sailor who manages the ressel? Who invented the telescope or the quadrant? Was is the mechanics who mandactured them or the men who reap the benefits of the invention? Who discovered the progelling power of steam, as applied to boats for mansputation? was it the mechanies who mate the machinery or the men who direet the barque through the watel's? Who saved the labors of millions in the mamufatories of Hurope, by the inrention of labor-saving machinery? was it the mechanics who construet the mathines or the manutarturers who are benefitted by their ereation ?- No; it was men whote labors and investigations were of a higher order, aisl who were raised up to gladden and adorn the history of ages-'(was the Newtons, the Iferscliels, the Priestlegs, the Arkwrights, the Fultons and Franklins of the times, who elevated seience to other worlds, and bronght down her inspirations to bless the lumblest departments ol the earth which we inhabit-1o pour floods of light and knowledge on the walks of industry and domestic convenience.-Had you left the mechanics and artiane to themsclice, the measure of their usefulness would sow be settled by a fal diflirent standard. It has been to such men as Dr. Fordyee, Sir Arthur Young, Dr. Anderson, the Duke of Bedford, Sir Juhn Sinclair, and Sir Humplirey Davey, that England is in a great measure indebted for her goreatness as an agriculural mation. Sir IIumplney Davey has delivered a profound and able course of lectures on $A$ urieultural Chemistry, whieh he will hereafter leave as an invaluable legacy to makind, and which has rendered him an illustrious benefactol to after generations.

We must all agree, that agriculture, in many counties in Europe, has, within the last century, been vasily imprever! The moderus have far exceeded the ancients. Bhy what means have they done it-by learing the farmers to them. seltes? have they been ieft to apply the seience of botany. chemistry, mineralogy, and geology to their useful labors? will any one have tue harlihood o deny the henedrial appli- 
ation of these branches of sedestec to stgrieutural attair. ments? What but chemistry tanght ne the virtucs of gypsum, the great and wonderfinl fruetifier of our soil?

Let us inquire, then. how other nations have rapidly pro. gressed in aypicultural improvements. and by what meanthe state of New-York unst adrance this fundamental bramele oin industry, this true and unfiting support of her strength and grandeur.

In the investigation of any particular system of public poliey in this country, in relation 10 a stuecihice object, it is consistent and necessary to look at the course pursued by other nations. If their plans have been suceessful : the ueans by which they have been promoted and executed, should be the subject of inquiry and adoption, when prociseability will sanction it. In France. in Ltaly, Germany, Sweden, Denmark, England, ant other European eountres, the art of dillage has been earded to a great leeight of pericetion. rhis has been offected by at systematic course of measures, commenced with liberality, and prosectited with unrensing excisy and perseremance. In point of matural alvantayes our own state, as we bare shown. is equal to any county in Europe. of the same extent, when the whole compass of ous: physical resolures is taken into conshderation. Will the means, then which have been embraced in Caropean nations to reach this state of improvenat, latve the same tendency here, or have we the ability to adopt these means?

In modera Eurome, A mricallere for several centurics, was

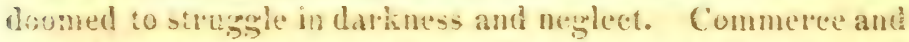
manuficture, alluing and gratify ing a spirit of trafie am!

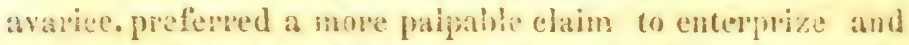
invention, thas the eultivation of the sgil. It was not, unth the most distinguisied classa's of society pereeded the hight impontante of giving to the oecupation that mantinins ads ethers-it was not, unti? pubite writers and politieal econoshists, printed out, ify convineing and unanswerable reatsur -

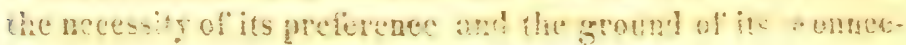




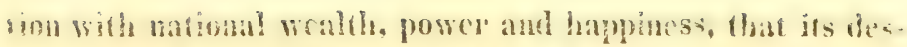
thines wape a mote illustrious east and were doomed 10 exhilbit a more suecessful carcer.

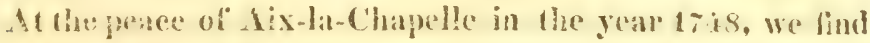
that the difterent Suropean govermments, embacing in the seope of their policy. The most distinguished men of hein times, commeneed a liberal and hightinialed system of chrouragetment to all the arts ol husbantry. In Italy, a renumrey whose brilliant acruigitions in the arts and sejentes, have gyiven her a celebrity that molitical degradation ean do stroy, men of science and fame rommened their labdahte exertions, and imparted to ayriculure, all the assistance which leat:nings. stuly and experimest could extenl. In tha Feapolitan dominions. 'Tuscany, Sardinia and Ferrare, ant at other plares, hooks on this sulgeret were witten, translat ted and difused. and men of emburnt aernirements sent abroad to collect information. Promees and subiects иere alike seized with a kind of enthusism, and rapidprogress was marle in every species of rural cromom. The universities of benmark, Swedeu and Ciertany, at the natur perod, instituted cxtensive and luminows conrses of atriceltural lectures, ant disseminated light and improvenent to 14,6 matsantry ami cultivators in every guater of the difierent contuldes. The courts of Denmark, Sweden and Cermany tuebs a peculiar interest in every exertion of this deseription. In switzerland learned associations were furmed, consisting of the first mera in the different Cantons. who made beneficial experinents. and opened an extensive corpespondence wiat the varuns states of Europe. Whe ought not here to forget the two jourmals printed at Leipsic and Hanover, one called the Journat d' $\Lambda$ griculure, and the ofher the Recucits dillanove, which did much to inform the north of Europe and enlarge the splere of this useful scicnce. 'The great and immortal Linnats, devoted a great purfion of his time to improvernents in this department of useful labor, and more particularly in re. lation to foorl for live stock, and drew round him a congre 


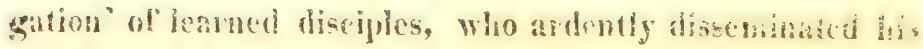

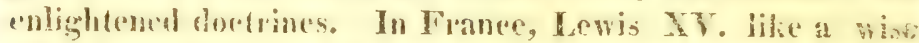

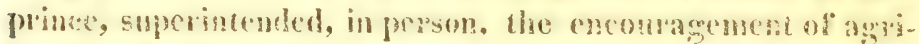

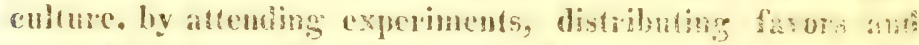

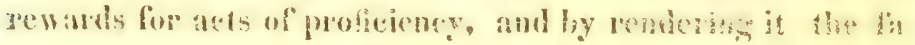
vorite pursuit of the French people. Extersize socierios

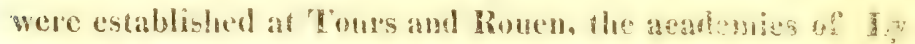

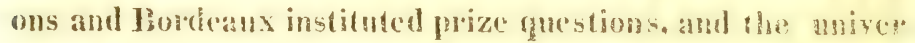
sity at Amiens stocd light and truth on many important sals. jects. Philosophieal traets and literary publications have

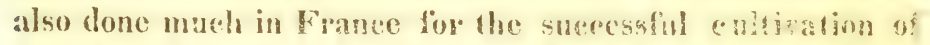

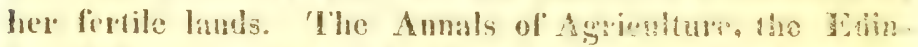

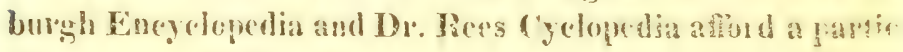
nlar account of these immerements.

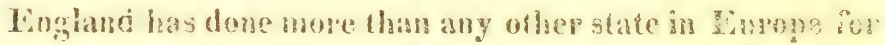
the eneouragenent of anriculture, and her suecestul rexpl

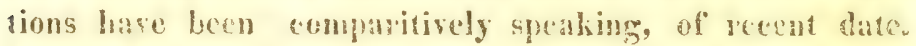
Some eforts were inderd made unter the reign of Gures:

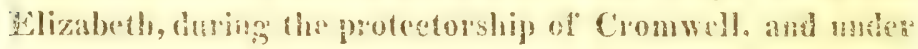
the governinat of the Stewarts; but they were seatried, feble and pardal movements. It was not unil the mithe

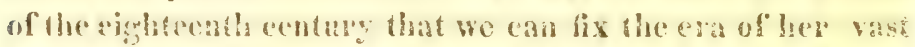
monerements. Since that period. the writings of lonng. Marshall, Anderson, Jakewell, Fondece, hesmeith, Sut

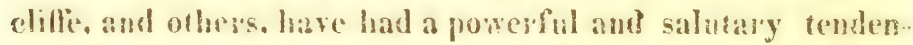
ey. But it is to the British Board of Agriculture that Eng land is imlehted, to atm incalculable, exient, for her prese:s? superiority and greatnes in this hanch of politieal economy This board, which was established ly the bold and patriots rxertions of Sir John Sinclair, a man whose name should be

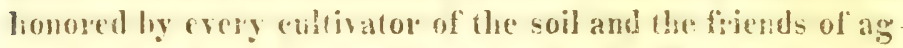
vicuiture in every eountry, hats produced cflects as lasting as the power of kingland, and of more conscequence to mat. hind than all he! bribiant militay exploits. This institurob. which holds ont a proud and illustrious example to ev. rry civilized nation on the globe, has been the beart and con. 


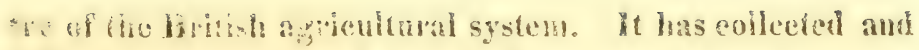

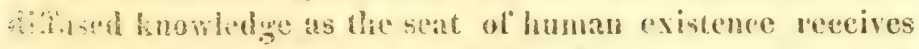

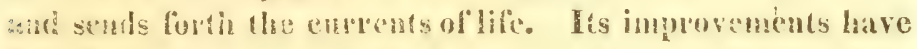

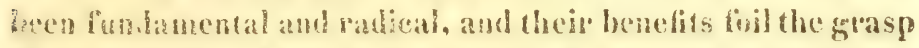

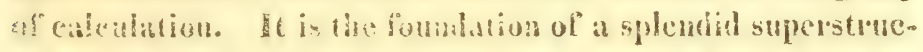
ture in agriculcura? seienec and industry, that will stand a

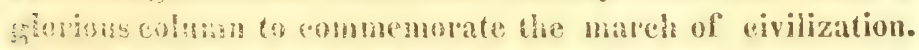

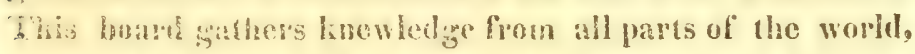
7. poums gpenens of every valuable production in distant chimates, proeutes ath domestic animals wolthy of eneouragement, ohatan a knowledge al all new diseoveries and invencous, foster's salutary experiments, bring new principles inio byoration, rewarls all distingnished improvements, and Aastly, extends the linit of is restarches and acriusitions to avery cothage and tenunt in the british dominions. Let these liats be duly weighed.

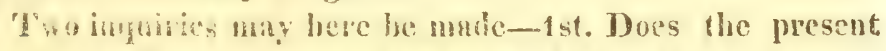

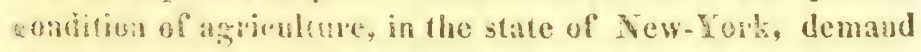

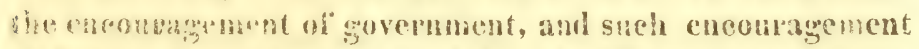
as forming wions have entended? 2d. Have we the ability and resources to give this patronge?

14. What, let us emutre, have we done for the seience of agtic uhtue? What phlic countenanee, what indieations of

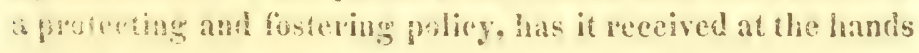
of our state government? 'Phe direct answer to those questhas ang he lond th the beport of the jont committee in

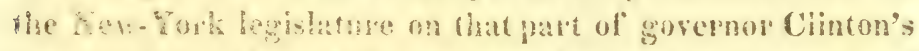

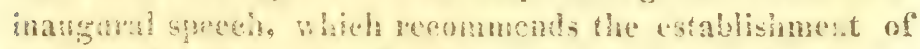

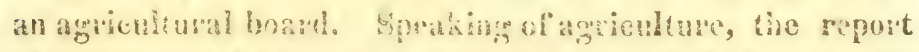

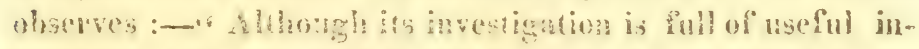

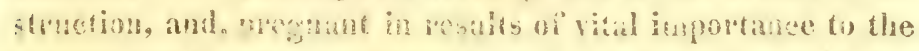

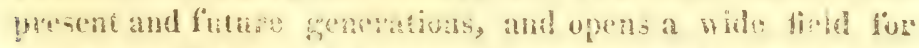

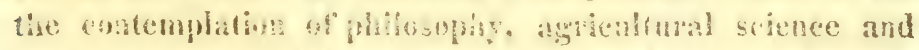

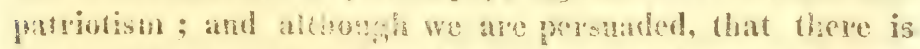
wo conoty on carth, whase inhabiants abe ixttey informed

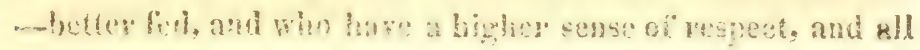




\section{$\therefore$}

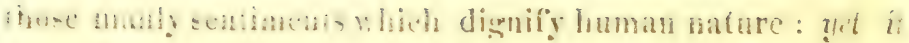
is preinful to cadd, that are are this monent in a slate of ab-

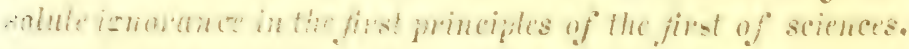
as connected with clicmistry. We ure. also unceruminted will the fundtmental grounds of those great modem im-

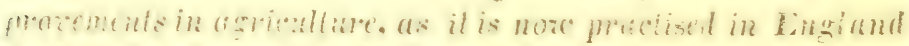

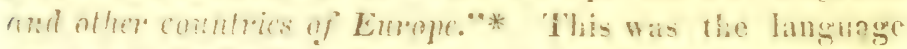

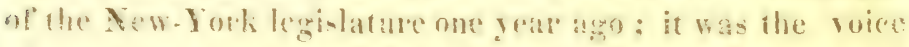

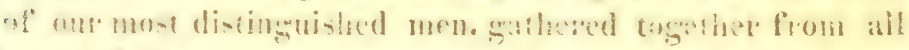

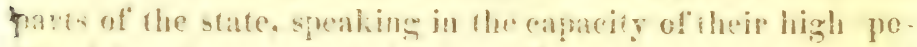

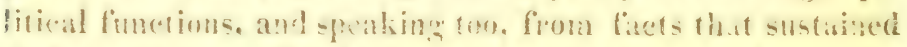
lucio asertions. We have mate no great general exerlion rewards at radionl change ia this fondamental branch of in.

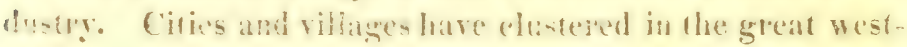
crn section of our state; a population noble in views, ricl in phirit. and liberal in action, lave erected monuments of improvement in every section of their country. They sustitin. to a properextent, otir plans of intermal trade; taste.

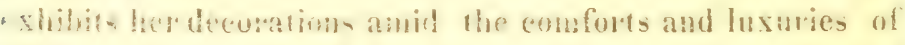
life: and science has been weleomed to temples worthy of

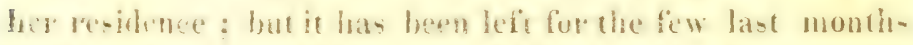

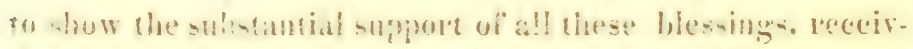

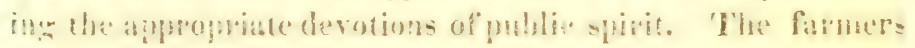
who are located on the border's of our (wo grreat rivers, pos-

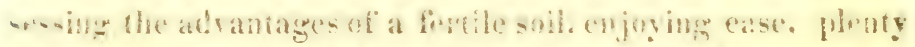

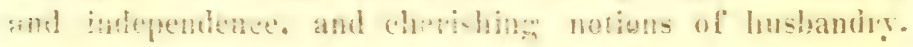
which, in mamy cases, were breught from Europe at a preriod when agriculure was in a far diflerent state from what it is now, in the same ynarter of the world, have not struek ont new punges of inmovement. "To this remalk, there are, however, honorable exeeptions. That prostion of our community which oreupy the seaboate have been interested. with a pattial rescevation, in commereial pursuits, and as we should consistently expeet, under past cincumstanecs, have

* Vide Mr. Livingeton's Renont ju Arw-Yorls senate, Februa-

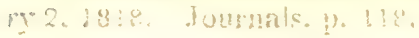


bet produced any eminent aeguisitions in the sciegee of which we are treating. It is not to be denied, that in the siste on New-York, there are men and cultivators of farms, who confer mach respectability upon the pursuits of hus!and? : but we mean to attarh general features to our rematks, and we do say that New-Yortin, in agrieultural attinments, is far thehind some of her sister states. She is behind Miassachtisetts, who deserves lasting eredit for her high minded exerrions in this resprect; she is behind Connecticut-she is behind Pennsylvania, ahd, on sone aceonuts, behind Virginia. New- Fork, second to none ol her ansociates in the contederaey, has grossly slighted the mighty means placed in her hands for igreat purposes, and disgaracefully slumbered over hev neglected resoures. Gine has not slept like the young lion in his covert, whod weakness dietates quietude and dimidity : but she has slept like the liev, wien his ege kimbles in conseious majesty, and his limb; have waxed strong for domiaion. Inad the leading and powerfish men of our state combined their effurts with the farming interest, ten years asgo, to raise the condition of acsiculture ; had systems been formed to encourage bold and ogrginal efiorts and to spread the blessings of intelligenter ; hal spreat minds led the way and corresponding exertions followed; we shoult now have stood the admiration of the Ameriengraple, the aduination oi vilim er nations, and the promb and cherering example worthy of miversal imitation. What has not been done. only shows what must he done. It now bereomes us to by the figundations

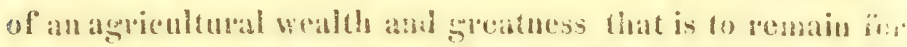
ages. Let the basis be firm, dees and broad, that the co-

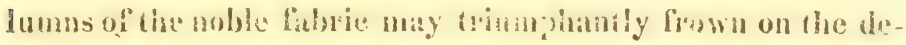
predations of labe, and the revolutions the move in her fear. ful train.

* Timothy Pickering in Massachusetts, and James Madison in Virginia, have both delivered agrieulural addresses during the ast season. The age of the fommu siges has revived. 
bur hese ingury is, have we the means and ablity of es.

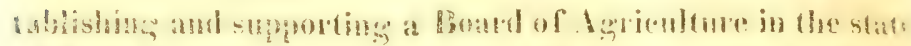
of Nesw-Yosk? From the shores of the ocean to the shores

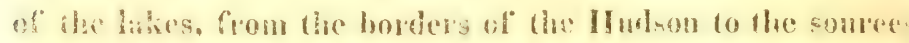

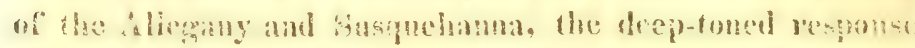

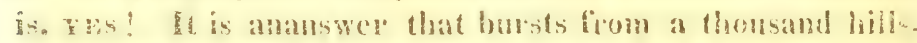

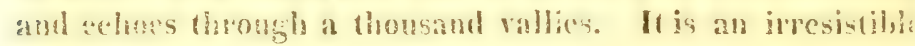

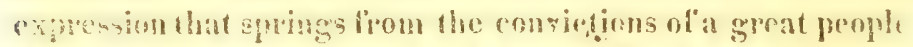
It vantuishes esery doubt, and silcues thefoint and seatter cd tum rusting's of́ prejudice.

Siates and empres move with an intpulse whose stsenghts

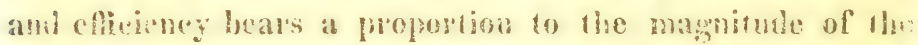
inciting objects. When a nation onere chters the broad yat

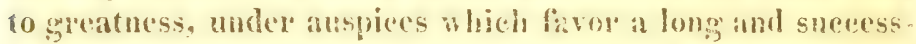
ful career, she moves on in the plenitnds ol heg power and eneresy, untif she reaches and aceomplishes every ebd and design worthy of her high and tancentant dostinies. These remaks apply to our condition, ald in turning om eflorts to one branch of wealth and industry, we aye not to forged another which sustains it. In opening vast clamels of in. ternal conmerce. we are not to formet that agrisuture is the batis of trate-that its encouragenent is the first dury of a commonwealth.

A new eradawns upon the history of onr agriculture. The mast year has been frutful in the inception of gurest plans to foster its interests. He can now number ahont 1 wenty agr-

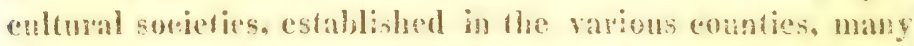
of which have gone into operation wibh the mest bupry and

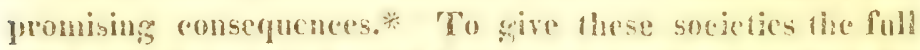
effect wheh is 10 be berived from such associations. it is re. quisite that there shouh be some rallying point, aromu which

* There are agricultural socictic in the following counties, either formed or forming :-Sulfolk, Westchester, Orange, Dutchess,

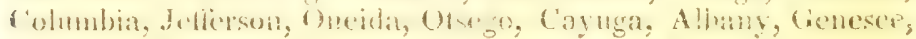
Corland, Chenango, Herkimer, Saratoga, and Queons. In some counties there are several socicties. 


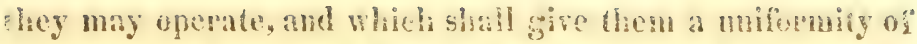
chancter and action. It is not to be expected that eounty socieres, supposted by individual defort and liberality, eate

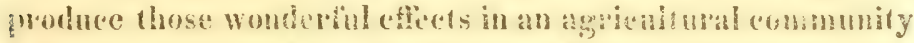

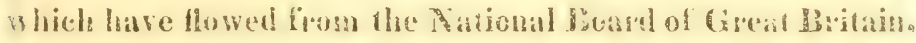
stml wheh are atlended with expense and protracted explon. their resourets are too limiled for this purpose, nesthe to they (c)-operate subisently wish each other. These are, in their nature and constibution, calculated for suburdinte combinations, that will produce excellent results as constinent parts of a great and well organizerl system. What then is wanting but a RoAno of Agucurrede, established and patronized by the liberality of the New-York state government? 'This is requisite, as will som be slewn, to give vigor and consistersey to our present eounty sociedies, and biduce the ofher counties to form similar associations. Each county would have a chain on the labors and expenditures of the Goard, and of cotirse be induced to enjoy this mivilege b: taking the necessary steps. The expenditures of such a board, and the resources of the state to support them, next bill under our view.

'Tlie Report on Agrieulture, made at the last session of the Few-Fork Legishate, embraced the following oullinesshe Board was to be established at the seat of tiae state gosemment, consisting of one member from each great dis-

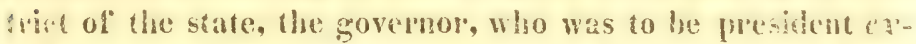
aficio, a professor of agriculture and chemistry, and a su-

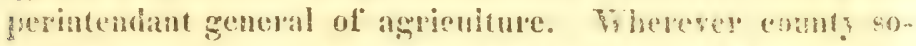
rieties were formed, each society was to recive a proportion at the public fund attached to the lboad, the disilends to the countes to be distributed as preminum and prizes for a sibitions of excellence in all banches attached te ablisen?. are. 'To sustain this great instivatum, of to use thi worta of the report itsell, "to establish and stpport shis s? fabric, franght will consequences of incalculable besatit."

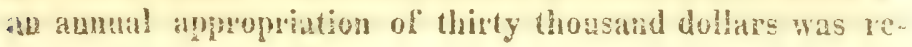


commented by the joint conmitec of the honse and schate

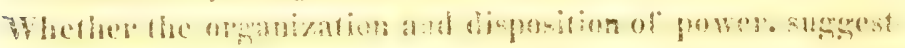
culy the report, was espedient of incspedicnt, is not the subject of investigation in this exanination; neither to we rave so much unler what form, how, of by whom, the power is exereised. if the legishature will give power, and suffer it

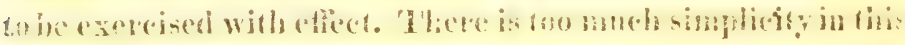

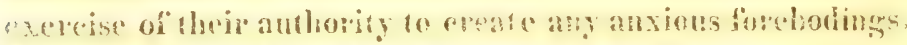

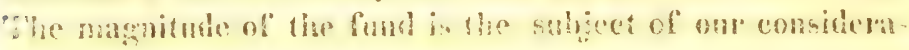
fion, and that thing thousand dolbus is none 100 much, appears strikingly evident. This stm the state ean set apart out of its surph funds. We ats.' not fon taxation-We only ask for an humble portion o! the cacess of revenue loyout our state cxpendiures.

It becomes every state ant eresy govenment to aet rights and to act with consistency. Sicw- Vork has, for years past,

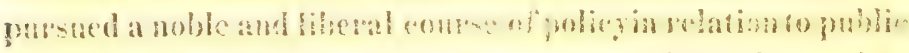
jonprevements. When we look at what ve have done, when we look at what we ought to do. and at our eapacily to do is,

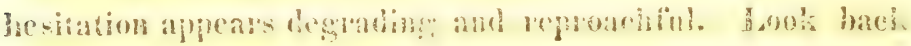
and see the magnitule of our appoprations for uselul purposes beyon! the ordinary sphere of legishaton. We have

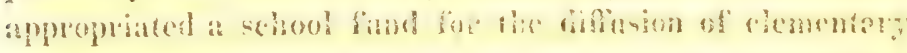
cducation, whose monies investul in stork. the rahe of lant and other property attached to it. amomt to $\$ 6,675,129$.

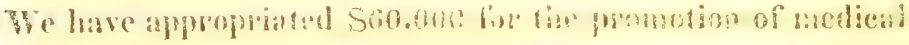
seience; we have given 574.268 i5 for the eneouragement

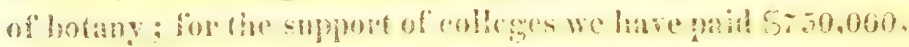
and for academies $\$ \$ 00,000$. Jere we find an appropratoon of" was" than seven mi!lens and a hall, whin the last

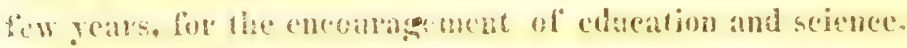
For miliary expenses we have apropriated nearly thee

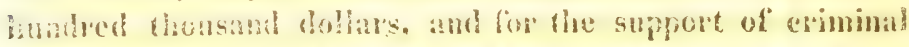

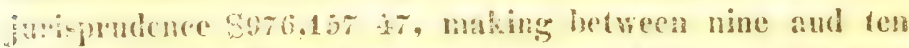
snthens in the whole. for these mrposes. In this partial view of en liberality, we say nothine of the aproprotions for more 


\section{3}

than sixteen hund'ed miles of turnpike roats, opened by t.a state government, in conjunction with individuals and corposations, and of the thity-five on iorty bridges, which, for the most part, have been erected during the last ten years, in the same manner. It is with pride and satislaction that we re call to our minds all these facts, sonorable to the chane ter of the state.

During the last war with England, New-York did not shrink trom sustaining the falling eredit of the nation at the darkest perils of the erisis through which we gloriously pas. sed, and from providing for a debt falling bat little short of two millions of dollars at the conclusion of this contest. These facts show that we have resources, and resourees too, in every respect, anple to meet the expenditures for our in ternal improvements.

What is now asked at the boarl of the treasury? Not a disbursement to be confined to any particular class of men as it regards the benefits to be produced; not a gratuity whose enjoyment is to be limited to any one professional parsuit; but we ask some decent expression of bounly, some moderate encouragement towards that branch of industry from which all others receive their life, their nourishment, and their vigor. We ask the guardians of our public welfare, to extend the basis of our wealth and power as a state, by a public cxercise of that authority with which they are clothed by the preople. Commerce, manufactures, and the arts, have drawn their vital nutriment from agriculture. She has enabled our ships to spread their canvass and plough the ocean; she has fed the artizan, and given him the ma. terials of his oceupation; she has erected temples for the arts and seiences, and opened her treasures to give them peeuniary aid ; she las covered the border's of our waters with splendid cities, towns, and villages; she has sustained our treasury, and sent armies into the field to fight the battles of our country, and reap the laurels of vietory and renownand through all this, while fifty years have rolled away with 


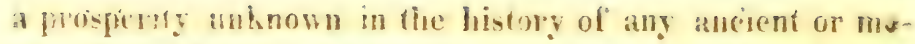
sern peeple begond the bosom of our own republice, she has merer raiscel her voice hut as a bexeracrasss! She now speaks in an homr of raciouled prosperity. She demambs not that oflure yrofessions and ofher pussuits should contriAnte to her benedit: but sle asks their premisaion to retain : fumble portion of her own munitiven confributions to the, gesources of our treasury, for hor on improvement, dhat she may do still mo:e for uslires. It is time that the culivators of the soil shouhl he heard. While haw and Physic, while Gommceree and Mamulactures have lilled so large a space in the public eye, we have too fal forgottea the Farmers in our Iegristure houmly, the have and hardy yeomantry who in jeace and in war, in prosperify and in misfortune, lave hornt. the stute upon their shoulders, and opened their hreasts to

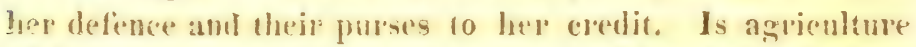
of less conseruence than orher subjocts of legislation? From thic ba:andit of indusiry sha!l the New-Iork Jegislature rum silh a cold bearto a penurious spirit. and a contemptuons eye?

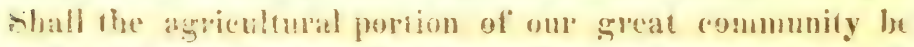
imbed away frem the latls of public deliberation with scom! and derision: We choose Jecrislators and rulers to propect and

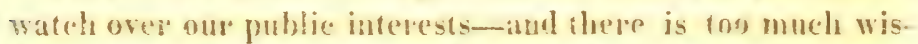
som. too mueh patriotists. and coo much biberality in the exe*utive and in the legishatro, to treat the encourasement of ajpicultore in aby uhbe mamer than its vast importance de. scrves. I, ark at our state. whose commeree throws an annu-

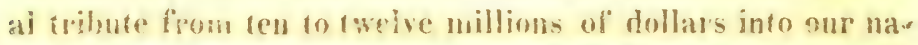
tonal breasmy: a state whose revenue is half a million an. mually : a stafe which has paid nore than ten millions of dollats for extra expenses within the last few years: a state roo, whose commerehal emporiun ean even mise fiom two to Rirec handred thousand lollars yeariy for internal improve. ment-look at these facts, consider that eighteen years lasw gassed away without a direct tax by the state government. ant beg louk at this call lor the encontragement of agricunt 
ture-onis thing thousand dollars, this sum that is even less than the sisteenth part of our incone? Was the state of New-York peor and exhaustad, this deuand for a trilling partronage would not be asked; brit we have had the assurance of Governor Chixtox, that after all the expenses of gevermment should be defrayed on the most liberal seate, and our taxes reduced one ha!f, that there would then remain, S.300,000 to be appropriated to purposes of public improvement. What prefers a stronger claim to patronage than Agriculture? Let an enlightened and reflecting lewisiature answer!

But to conelude on this point, where argument is not requisite-we merely ask, whether we solicit an anunal appro. priation, as a perpetual drain upon our treasusy, without at re-

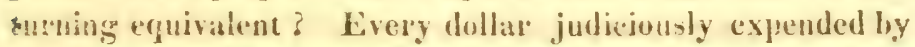
an Agrieulumal Board would yedd an abundant return in tho immediate rise of our real estate. Our products "wohld inerease, their mature and qualities be vastly changed, oul latbor beeome far more probluctive, out lise stock be inproved beyond calculation, and a spirit of emulation and enterprize awakened throughout our state, whose etionts and example would be felt to the limits of the Ameriran Linion, whese liruits would reach, through the medium of our wide-sinread esmmeree, the boundaries of the globe.

Admitting that a Board of Agriculture is established in this state; that the Legislature, With a beroming spirit and magnanimity digest at plan and oryanize a society, the prinejples of whose constitution are franght wills wisdom and dis-. eretion; that sellishness aud personal ambition are crushed with seortu and indighation, party animosity lost in a glow of enthusiasm and unaniuity to serve the people, and a stand rakea 10 promote the agrienliumal interests of the state of Sew-Tork, that deserves the most unqualified praise and resiect throughout the Anerican community-under these

* See his Inaugual ddilies, aud also his last speect? to tho Legislature. 


\section{6}

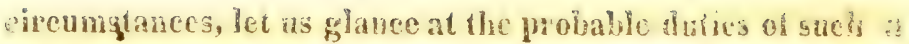
board and the eflects which must be producet by their discharge.

A complete linowlespe of the Agricultual proures of the state would natural!y follow. 'The temberature and va riations of our climate, with it setfiets on blu productin.. of the earth, the various chancterintics of our soll, ans the products best adiapted to its dillereat linds, would wetripy ato early notice. Sut litte attention has yet beren graid. by any systematic efforts, to the dificent departments of our matura? history. It is time lhat our mincralogieal lingtum was explored and its treasures opened to the world; it is time thas our geology was examined with minute attenton and ample maps marle of new and old discoveries; and bur vergetable and animal lingroms present a wide thestre fur emionily ansed investigation. 'ilhese hranches of naturat history bull bereafter exhibit a more inthate alliane with agriculsure that me may now imagne. Di wonh be policie for the board to open an extersise rabinet for the depost and preserpation of she specinens and examples of nine whong, we whogy and botany, which time and indas!ry should bring tegether. Suds

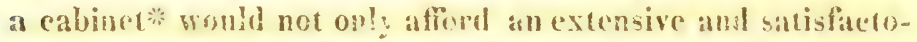
ry knowled of of the natural history of our siafe. but wouks in all probability, gereatly atvance the natural sebence of the sation, by becosting the reposilory of simbila ypecimeis from every section of the Cnited states, in exchange for mang which the board could distribute. Culd the direetions of shis institution, we could not only ascestain the gablities of our soil, but the antome of our ammal produetions, the extent of our hone consumption, llar yearly increase of our popula. rion, and the immorements of dmatic industry in sanerst

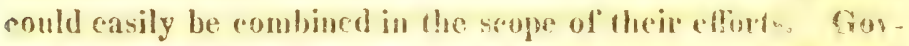

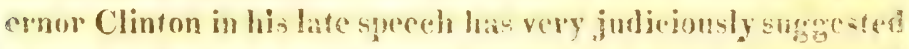

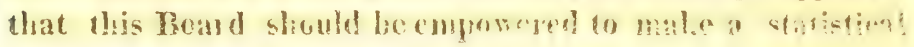

* Seo no Mitchil's icter, which follows 


\section{8}

survey of the state and extend their atention to the varion: subjects here noticed.

As the application of seience to the pursuits of agriculare has engrossed the attention and patronage of the unost distinguished modkrn economists, and the mont distinguished agricultural nations in Suroge, the Board of Agriculure in this state will frepeeive the importance of ereating a profissorship of agricuhue, and the neessosty of having gegulab and extensive courses of lectures on agrieudumal ehemistry.

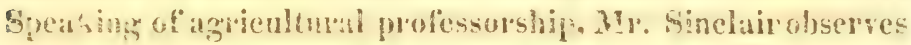
- $1 \mathrm{t}$ is not many yeass ago, since, at the expense of a pri.

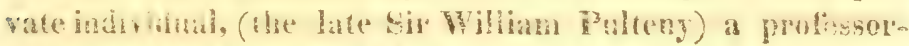

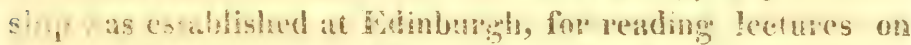

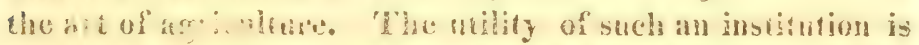

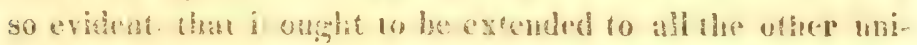
versitics. 'Rue sttention of young men, by such establish-

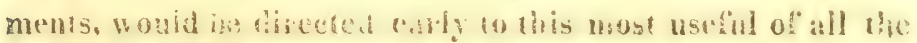

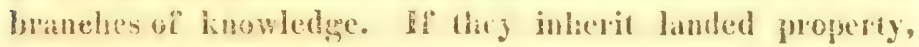
agriculture is the topic to which their views shoald he patrticulary directed ; and ats there is searedy any protession, which will preclude them from spending some part of theit time in the country, if aller having aceumulated a fortune, they becone propretors o. labd, their having oarly areguired anch knowledge, would be a souree of much gratification and advantage." But such a course of lectures would not be contined to the rising generation; heir benefits would immediately reach the farming interests and cultivators of the suil, who now sow and reap the harvest. The ligh disseminated would be extended to all parts of the state through appropmiate channels. Comnected with such lectures, ve might expect the atloption of an amyle system of seientife experituents, to asecertain the specific qualities and composi-

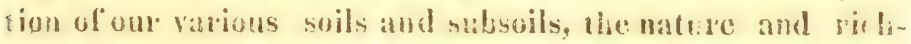

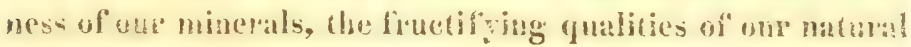

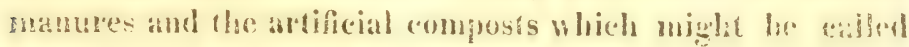
to our aid to enrich and fe:tilize the arth. 


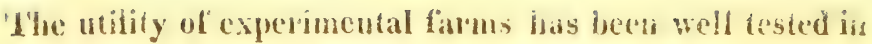
fiermany and in other quarters of burope. It cannot be exprected that the cultivator's of our soil can afford to set apare a ecrtain portion of their lands for purposes of experiment, at the hazad of loosing the atwomnt of the ground rent, the io labour, their time, and the mon'y expended in the allempt and yet experincent has proved, and ever will grove, llee soul of useful scienec. Should the Board of Agreulture have small experimental farms, or ectrain fores of had appoptialeal to the growing of his or that particulat hind of prodace, mathing the distinctions between diflirent hinds of soil, and

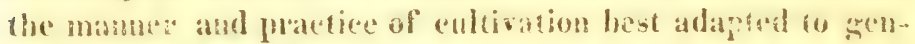

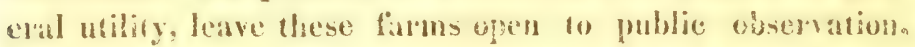
have the contse and varions opelations of the experinents, publishret to the commonity at latge-introduce o:s these farms bedin, plants, fruith, and all hinds of valuable vegetat-

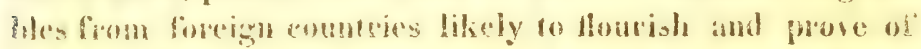

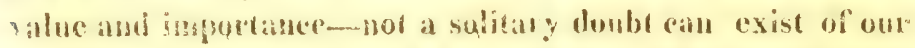

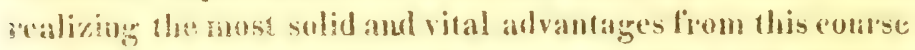
sif polie?. It has beenby such expedients that other wations mate disar so much for grast subsistence firon small and limited means.

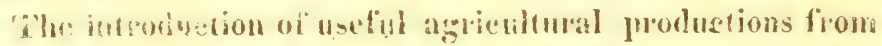

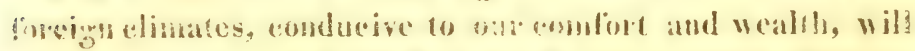

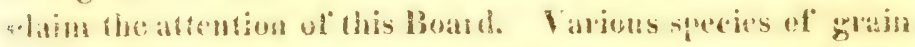

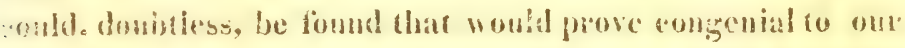
soil, yerit a more abundant haverst frem the satme quantily

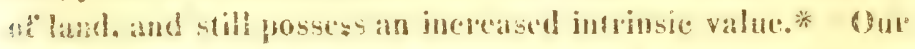
sols will be found to gitel masny valuable productions now

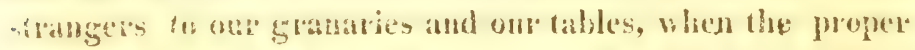
lest bis aplised. It is not for molividuals to do this. Expe-

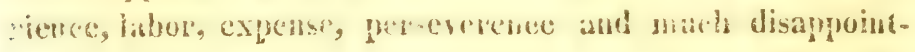

- Ginchon S. Mumfo:d, esq. of this city, about two years since, aceidently met with a small quantity of a peculiar kind of wheat an bant at vessel from the Hediternamean, which has nroved to be

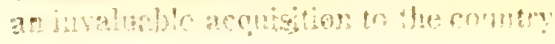


mont must altend the efforts to increase these blessings. In the article of linit in particular, our lands would prove susceptible of great change and improvement.

Under the anspices of this institution, we night consistentIy expect great improvements in the construetion of all imfortant implements of husbandry. Inventions in labor-saving machinery have been much attended to within the few last years; lut the study of arnte and enterprising men has been more particularly turned to labor-saving machines in our manufictories. The same ceonomy could, to no inconsiderable extent, be applied to the cultivation of the earth and the farmer partially relieved, in many instances, from that te. dious and formidable application of physical forec and exerrion which now attends his ocenpation. But it requires a liberal and permanent patronage to great mechanical projectors under the attention of some enlightened publie power. to effect this end.

Another duty which would naturally fall to the provision of a Board of Agriculture, would be the judicious distribufion of premiums and rewards to individuals and the county socicties, as suitable acknowledgments of merit and exsellence. 'The most alsumlant erops firom a given portion of soil, produced at a specilied cexpense, as well as extraordina. ry sucess in the raising of useful doxnestic animals, wonld be entitled to something more than verbal indieations of approbation. Whatever should be fomml of great and slable stility in the agricultural department would deserve the pesuniary attention of the board, so far as to render it an object of pride and competition.*

In ofher respects, besides the excitement of our pride and emulation with respect to the raising of live stock, we may expect improvements forn the Buard with regard to the most judicious nethod of manging domestic animals in the apportionment of their food, the mast proper and whol-

$\rightarrow$ See Juige Itertellis letteg which will follow on this subject. 
sume food to be distributed, the discases inchent to therin, their nature and remedy, and the improvement of our present species, by the introrluction of animals from forcign countries. The introduction of the merino sheep, and the importation of some peculiar brects of catte, especially into the state of Miassachusetts, afterds a convineing lesson on this heal. Veterinary knowledge is becoming a branch of economy of the first appreciation in Creat Britail, and deserves much mole consideration than it receives, in our own country. While great attention has been paid to eattle and sheep, the noble horse has been too often gr'ossly neglected. Should the Board of Agrieulture have lectures oceasionally deliven'ed and published on this branch of linowledge, the effect would be highly conducive to our interest. It has been asserted that every pound sterling so expended in Erglind has produced a thousand pounds profit.

The recommendation of all such wholsome and salutary laws and regulations as woubl favorably affect the interests of agriculcure, ma naturally be expected to fall within the phere of duty appertaining to the operations or the society. f'ossessing every requisite information, the liond would constitute a source of intelligence to which the lingistature conld appeal with coufidenee and sueess. The depressed reputation of our flour in foreign markets. the great staple article of our soil, proves the palpable neeessity of some guardian eye to wateh over our agricultural concorns. It does not belong to a chamber of commeree, but to a hoard of agrifonlture to correst the evil: it must be rennedied at the souree.

Rozds, camais, brioges, hadors aml depots, are of primayy conseguence to the interasts of an agricultural community. 'he great improvements to intermal tade whieh are now whersing by the state goverument, will form the bulwark of an infernal interesurse not cqualled in the boundares of any mation: hut there must be may minor water channels. many ary qoads and other interust ronveniences, hat mose 
fe left to some effeient organ of public power, to point out wod tecommend to future patronage. What power could mone properly do it than the Board of A

In the first report of the agricultural board, we might expect a tull exposition al all those peribicious errots and eustoms, that are prejuticial to the most lisvorable and productive cultivation of out soil. 'The removal of obstacles wouh of itseif prove a vast fiteility to our rapid advancement in rual econony. Communities too often progress to improvement under a load of error, sanctioned by the enstoins of sucreeding years and generations, withont being sensible of the fetters that shackle their energies. 'Hhis remark, in a peculiar manner, comes home to the arts of husbatady. As bhe boald of acticulure wonld have the neans of commanding a view of tize whole grround at a single glanee, mbeh might be expected from their clear and comprehensire perception.

An agrien?tural hibrary would be an oliject worthy of attention, consisting af'a collection of the most celebrated works on the subgere before vs, which could be found in this country and in Eus, ${ }^{2}, c^{2}$ bracing not only leading productions, but also reports, arats, eysays, periodical works, and philosophieal disajuistions. A collection of such works, as they appear in the difierent quarters of our own country, at the present auspieious era, would embody a mass of information highly use. finl to the state.

I'sc Board of Agriculture would not fial of giving a combines eflect to the exertions of ont present agricultural socicthes in the different counties, and those which will, no doubt, soon be formed. When our forty-nine eounties shall have formed their full number of associations, and unite their effoits under the protecting aid and patronage of this great legislative organ, elothed with ample power's to raise up and direct the slumbering energies of the state, may we not confidently look for consequences whose prospective conte mplation is suficient to gladen our vision and give new life ard 
Animation to our excrions? Iot not the imefletmig siph, pose for a moment, that the Board of Agriculture would prerend to dictate to the county associations, or interfire with dheir measures and proced dings. J'he county societies will proced in their own course, and theit improvenents be blended with the improvements of the Board. Reiber is the Buard to interfiere with the farming interest. It will place light and how ledge under the eyes, and in the panthwa of the culdivater to his fields, his gardens, and his ureliarts; it he rejuets this light, and chaves to habits prejudieial te

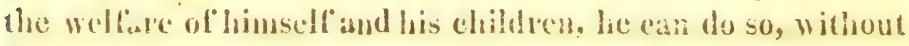
incurring erininal prosectition or contarening genal statultes.

'Were are naty highly respetable men, who imagine thas Whe county societies cin do all that is necessan?y to be dono

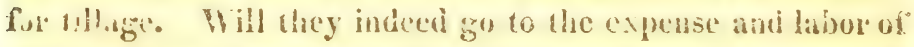
discharging the great dutes whith we have enduesated?

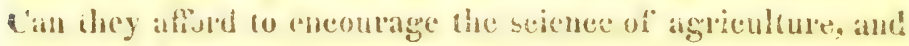

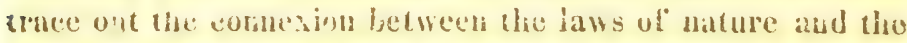
economy of national and harbithal existunce? Wi!l they corde-pond with foretgrn nations, institute philosophical experiments, public lectures, cxtensive surveys, seicntilio re searelies and investigations, import domestic animals, and excente all the duties incumbent on a public hoard? Reason intuitively rejects the supposition.

And, lastly, let us not forget the colleetion and diffusion of hnowledge which nust follow the establishment of this great state institution, whowe opreations, will, in no small de-

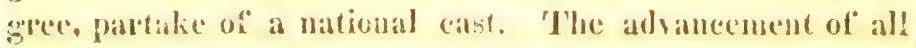
human hnowledge is propressive, more esprecially where it materially dependis on a mass of corroborating facts and the Jong repetition of experiment. We have before adverted (o) the depressed condition of aygiculure in this state and in the Cnited States. I wide and fertile field is open and unexplored, to any state, to any conbination of men, or any delefartion of publir antlingty that stands forth and leads the 


\section{3}

"iay ; it would be whe cinty of our instilution in publsh to the morld the results of all our inprovements. In the first glace, the light imparted hy licin labours would spread over our own stute, over the union at large, and even go beyond the limis of onr nation; on the other hand, the organ of the Boaml woubl opm a cortesponlence with every agricultural association in ont state, with every one in the Unitcd states - with every distinghished man-and every literary and scientilic seminary of sociefy, possessing relative information. The advantages of stch an intereourse woubl be reciproeal. liy this means. the agricultural resoureces of the nation would, in a great measure, be develoned; and we should go further than this: a correspondence of morent and interest wonld be opened with all quarters of the worlil. Throughout Eu-

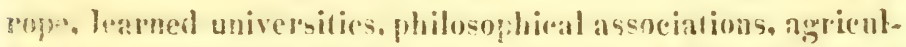
tum! iatituions, leamed men, economists, phitosophers and statesenen. would pour a floed of knowlerlye into the new wnrle, and the state of Kew-York form the great medium of its dilhision. It woubl be an honer, left to our own

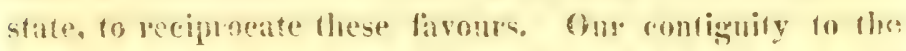
ocean-our commeree to the four ganters of the globe woukl mable us to do it with ease amb eclerity. This would pentel the reports of our hoard luminous and interesting 10 the gemeral welfare of mankind and tributary to the inprovenents of the era in which we exict. Our combry is daity excitinge more interest among the leaned of liurepe, and in many plapes in South Imerica, science wond send forth her luminaries and give us light, was there a lindred star with whose radiance their heams could mingle and expand.*

The efteets of an agrieulumal board seapedy need to be numbered here. 'They would be fouml in the gुeneral me. lioration of our soil, the increased value of our real estate, and the consequent increase of wealth, population, and pon-

* See Dr. Mitchill's letter which will follow; and, also, the last No. of the Edinburgh Revicw. 
s. The entivation of the carth wonth be perterest mats

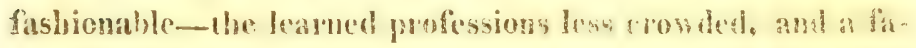
vorable bias given to the minds and incliations nt the ristege

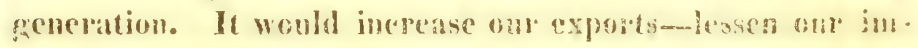

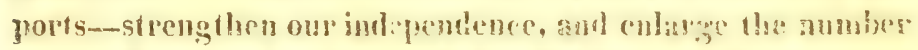
of our domestie comforts. It would hring ont he resoures of the state-zgise us a knowled in of dhe yarivas brambers of our natural history-advance tige arts and scienees-bring neglected talents into notire from anong the sultivators o:

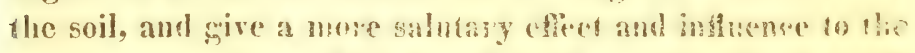

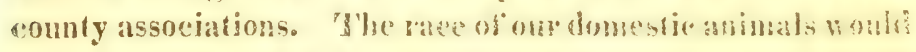

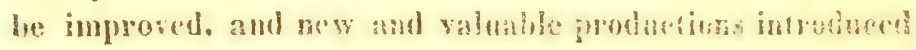
among vs. Its establishment would present at gramal am leading pattern to the other states of the mivis, and lite the

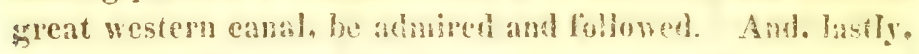
it would stand a proud culumo, to sustain the noble puliticat?

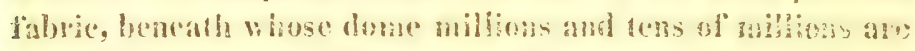
hereafter to grow up, flomish, and be hipps.

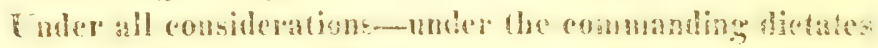

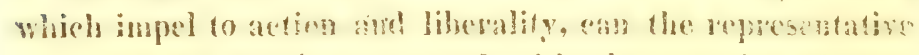
orem of the people, entrusted wh the exereise of theis

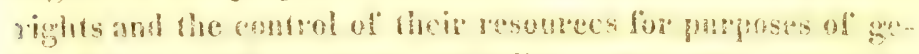

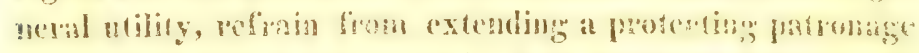

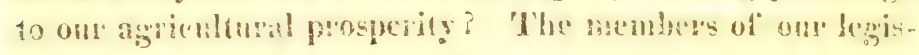

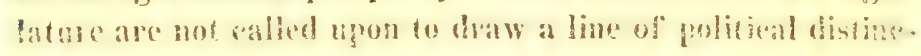
tum which shall cast the state into the arms of pultital wat?thre; they are not ealled ypon to decide on a mersure irs which the sensations of party of sectional fuds can bave nay participation: bat they are called upon by the lous soliciturions of pubice interest and genemal geod, to foum as

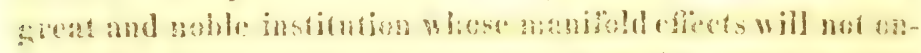

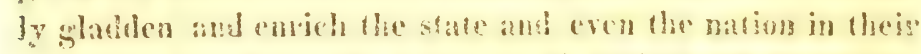

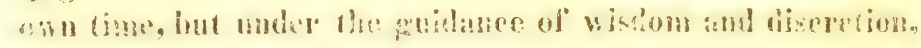
remain an evidence of legislative grentness, when the plock in which they live, shall have long been bended with the inges which have volled on befice us. A loand of A grien?. 


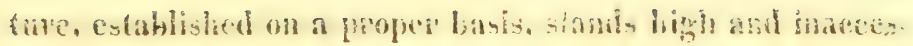

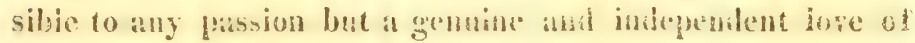
country.

It has been leit for the state of New-ront to arouse the - nation to the promotion of intermal imbovements. It has been lett for the state of Dew-lubh to bury party distinetions, in the eonarencement and prosectation of the greatege work of the age-a work, which display more grandent of

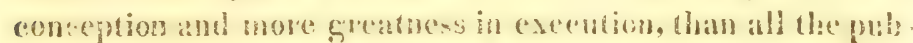

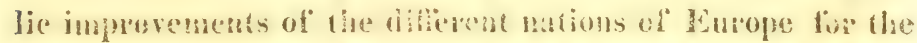
last hunded yars. And lef it he left for the stace of Mew-

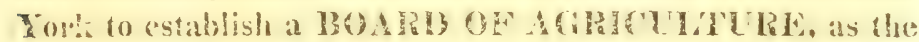
first instintion of the hind in vitr count:y, and this geresent another great ant illustrous example northy ite initation of the Ameriean states.

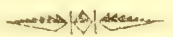

The following betters were athersoel to the Copresponding secentary of the Association for Internat Imporements. a few days since, and ate adked bere ats a valuable acequisilion. Ilany useful suggestions will be found in these

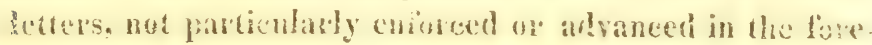
going pagres.]

\section{IION. SAMUEL L. MITCHTLI'S LETVER.}

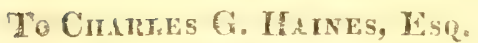

$$
\text { Peic-Kork, Junl. 10, } 1819 .
$$

Dear Sir- Yuur note of the oth instant relates to a subs fect of great im

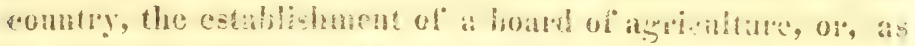

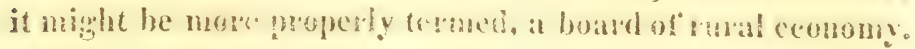

The govenon in his two seddresses to the legislature has

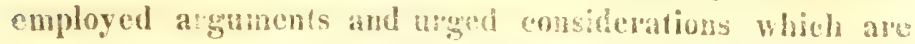

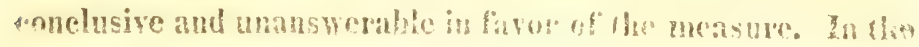




\section{.10}

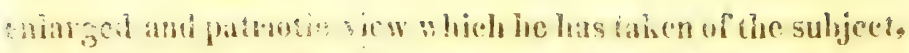
he las shown that the time is now arrived for foubling an institution where oflect, if surecessful, will be to entance tha salue of land, and to cuerease the glory of the state.

'Tle meditated establishment is both the indiration and the ofispoing of advaneral society. 'There is but little eall or ise for it, until man shall bave progeressel far in civilization. I have no doubt that our social rondition is nature for the speriment. It is an important brankh of the sovereignty.

let, if I was governed by indivilual or selfish consideratians, l searcely onght to wish suceess to the undertalitug. I should fear that my own importanec would be lessened amd my province iavalded. 'The hoard might interfere with my functions and with those of my lipents and associates, and aleprive us ol a part of the consideration we have gained, and continat to enjoy. I will specify my meaning by a few examples. The sosereign juwer ought to provide for the security of trasle; yet ships destincel from foreign places to Yes-Yoli, lakblen been ran astiore near the light House at Sandy llook, when lhere was no distress of wearher, and

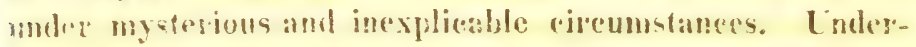

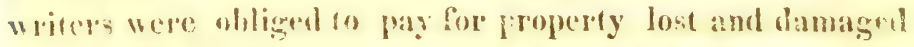
fhough this could not comprensate for the sufferings by pain and death. It was supposed there must be an error in the

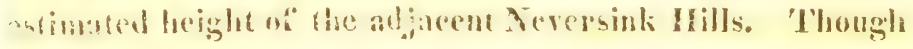

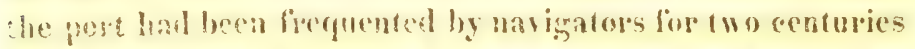

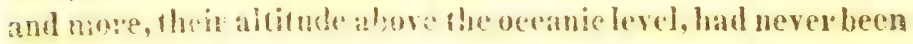
aseertainerl. It was comjectured to be about six hundred feet. Bjeing then a diractor of an insurance company, I determined 6) go andelf and fiad dbeir alliate. I company of learned

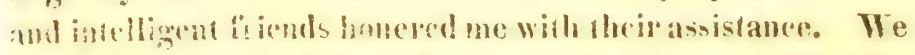
fombl the smomit of these fanous piles to be considerably fose than the hentred fert. 'The reasnn immediately ap-

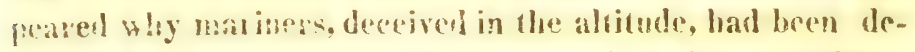

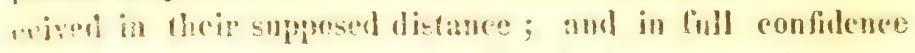

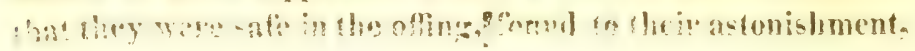


their vessels thumping on the botton. Since the fubliention of this discovery, the line of distinetion and the decoy to ship. weeck, are removed. 'I'bis beneficial work ought to have been performed by a board of internal improvement, in whose arehives the experiments and caleulations should have beck deposited.

'ihe sovereign's kitowledge ought to extend to all the regetable productions ol the soil. Whether they are lowly as zhosses or exalied as pines, it is his business ro know them. or to know where to find them. Jie should direet them to be preserved in herbariums, reggistered in ratalogues, and deseribed in books. Whatever the Almighty has planted in his dousinions, is a worthy object of his rerided. By the in. dustry and skill of the I,yecunt, the plants growing within filty miles of Jew-York eity, have been carefulty sathered and botanically examincd. I scientific list of them is al. most ready for the reading world. 'This honorable labor' sught to have been execuled by the board in whose museum the sperimens and their specific maths should he hept fo! vite information of all curives enquirers. But it will be theirs to continue and complete the undertaking.

The mind of the sovereign ought to eontain intelligence of the constitution and quality af the soil in his dominions. from the rock that hats resisted from the lecginning the assaults ol time, down to the dust dat is blown about by the blast, every thing hats its improblance; all ale parts of the estate granted to him lyy his Creator ; and if lhat catre is bestowed upon property which its importance demands from a wise and dignilied government, basuses wil! be adopted for preparing here a set of tables dise those in Mexico, where all minerals ase systenatically arranged with the places in which they are found. Hy own exertions, added by the hind and generous spirit of my fellow-citizens, has enabled whe to evllect a valuable cabinet of mineralogy and gocology, which is rippidy inereasing. 'Ilse day is appronching when die geognostie character o! an estate will be deemed a mat. 
ter of conserquence to the purchasel, as well as lane geome trieal boandaries and the integrity of tisle. Ite will not be satisfied until he knows on which of the great greologiea! formations of the ghtoln his plantation is situated, and whether shate, granite, sami-roek, limestone, chay, iron ore. wypsum!, matk, coal. black moukl, sand, or aby other miberal ardicles, predominate in his fields.

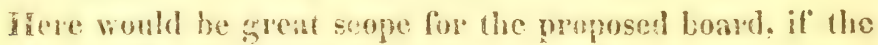
business had not alleady ben in a sorest degree acromplished. Fitey may, neverdeless, begin anew, and collect at samfle of every imgortant mineral and fossil from mountaing plain, and mine, and place it in there musem. This will be a commenechent af the right ent. 'This will be working to the prirpose. The pelicical economist, the practical tarmer, and the inguigive lavelle may alike see in a few hours cresy rave and valuahle production of the state, whether

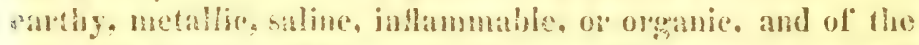

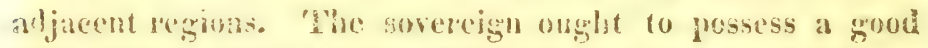
Siles of the configuration of his dominions. I, therefore, smot onit the mention of another subject of internal improveruest, that lies just linished hefore me. It is a profile al the cotntsy, from the manin of the ocean, at Lomg Bisanch in Jew-lersey, on a line near? north, exhbiting the bills of Temmonth connty and Staten Lslind, the Promonto sy of Hobeden, the Pallisado socks, along the right bank of

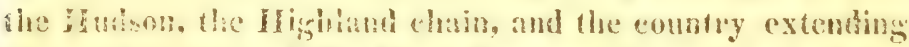

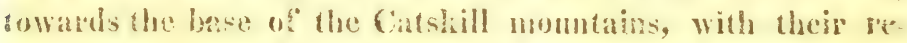
spective heights and distances. and theib golongal constiturion and chatacter. 'This leauthol and instrume picee of plysical geography is the result wi indivilual eflorts, longe and at length sirecessfully appited. The performanee lies ise my port folio, as a docoment to illustrate my public couss of matmal hisiony in the university : but it is a model worthy of the imitation and incpertion of seientife men. Suels survey and delimeations of select sectons of the councry

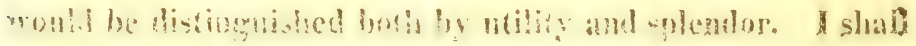


chunesate no more of the domestie fonctions of stroh a boari. Ihen number would fill an eqsistle of greater lengtin that Sare an inclintion to write. I must, however, notiet the telition of such a society to foreign places and persons, ant the honomble and excellent tendeney of agrieulurab comzunieations with foreign parts. 'llue illustrations are derivel forn my personal condition in life, and the ocenrences are of a recent dide. Cerain ingenious and enterprising frieteds pitehed upon me as the oryun of communieation with the mighty Czat of the north. 'The President of the Linited States and the Pansian Minister sanctioned my reguest to send a ploush to Alexamder, by the publie ship which earried nur minister plenipolentiary to St. Péelshurgh. 'Two of Wood's Erecborn uensils were forwarded, by the way of Boston, in the frimate (ruerricre-nne lob the emperor's eabiret. and one lor his field. The forme:, I believe, surpassed in symmelly an! ciegance every thing heretofore construetrd in the form of a jlonght. Judis: of it when you are informed. that the mouid board of this imperial offering was polished like a miruos. 'Lhis act would have dignified a board of agrieulture.

From the Botanical Garden of Antwerp, in the lingdom of the Netherlands, have arrived sects of the most useful flants for the kitchen garden, in extensive variety and exeellent preservation. Distribution has been mate of pareels of this precious eqonsignment to several of $\mathrm{my}$ agricultural friends. Many articles pemain in my possession for future distribution. A board ought to have possessed such a box of articles. They mighth, therehy, have been sent to all parts of the eommonwealth. But as it is, the particular friends and visitants of an individual, share the sceris thus east upon our ?ands.

A fow weeks ago, the messenger who brought ny dispatebes from Peru, delirered in atdition to the fleces of the Anerjean camels, and the silver nres of Peseo, a collection of

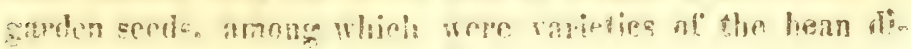


Jive from Lima. Whete being no boatu ol agrieulture, I sent them to the association in Gueens county foi culture. 'llhe band of Gorgophilists in Tuseany, courts a communication of sentiments, and a revinrocily of interesanse, upon the cul. tisation of the carth amb upon hushandry generally. It is a prout event, that florewe, the emgorius of laste and the mistiess of the arts, exterds the hand of invitation and fellowship to Xew-York. There ought to be a socicfy (o) reply to such a communicaton as 1 received but in the absenee of surh a public body, 1 perform the strice, and enjoy the pleasure alone.

It deserves to he known to our state and nation, that the actual govenumat of trance is inoessanty on the wath to proeure specianens of the matural protuctions of yorth Ane

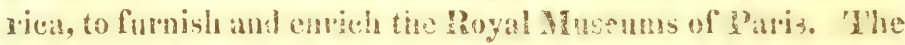
enterpising and diligent minister, in concent with the Acadeny of seinees, and in furtherance of the views of his go. vernment, is, by his agents, paratually cmployed in explos. ing our country, and in tamsmitting across the oecan the anticles he procures; if 1 am not much mistaken, the metro. f, nhit, of Wance will soon possess a betten collection of Fredish profutions, fian any place in the Tnited States. Why car: thei'e mat be a similar house of neience at home? A just regard for ourstres, would certainly leal us to acjuire a bet. tex knowhedge of the eomndy we inh bit than is possessed by any other fiegile. Aly communications with men of the highest ind higence, have lonses since satisfied me of the zeal with which gludpupels, bids, organic remains, and every thing is procured and exported.

Athe these disclosures, at rey few out of a great many, frumbly confess (1) you, alter all, that I am willing to trans. ler my share in the transactions to a public institution, ats son' at fhe fsoa:d which you and his exeelleney contemplate, shall he constitutenl. At Albany, the seat and centle of uscful works and ionportut opreations, a preat thoroughtares hom east, west, morth, and somth, might be the oflied for the warnt and distribution of all manner of useful intelligence. 


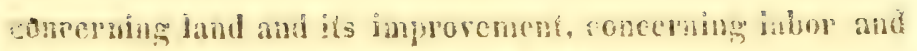

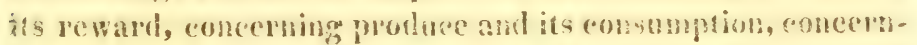

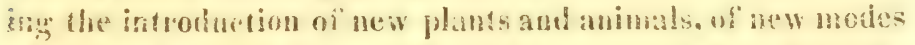

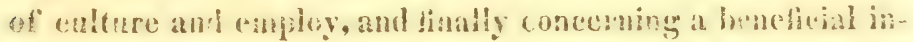

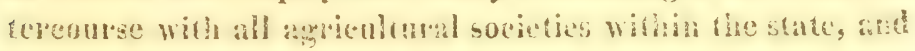
similar institutions beyond its limits.

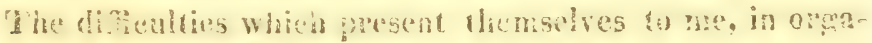

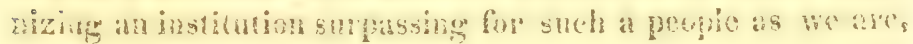
every thing done by Gotavitis the angust, Leo the fenth,

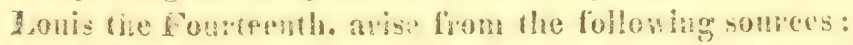

1. 'Flye danger of mahing it a political machine, in provide

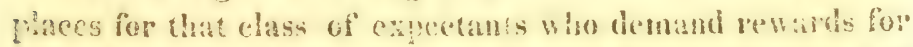

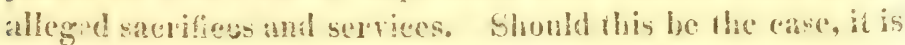
easy to foresce, dhat the great objects will be finstrated.

2. The danger of rendering it abotive from fireguent changes of men who adminislei its antars. 'llbe love or change and rotation, which has ruined the discinline of ome state prison, and the characier of oat ilour, will if indu!ged. be equally pernicious to a buard of Agriculture. Qualified and capable members should not be capriciously removed.

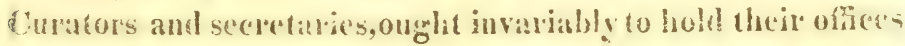
daring good behaviour.

3. The danger of impairing its esefulness. Alinugh envy and jealonsy amomg its members. This however will not molably be greater than in ofher eases where sereral persous are associated to do public business. Should feelings of such kind exist, as senso of duly, wibl uren af interest, may overeome them.

*. The dangeg of is failing thromgh the spyrehension of grent fund; to endww the sucicly in the first instance, and of barge appropriarions to stppont it afterward. Ny own opinion is, the it will be endowed at once; with the Governor of the state for a visiter, to examine how far the tast is observed or violated.

5. 'The dange! of miscarriage, from the indifience $0:$ lazions of the members. There will be so much smplos 


\section{5}

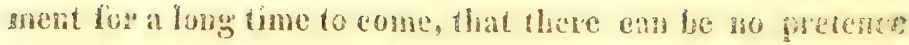
for languor or inaction. I should suppose the daily arrivats

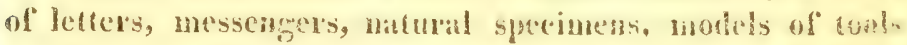
and utensils, boohs, plans. draw inges, atod the mumberken

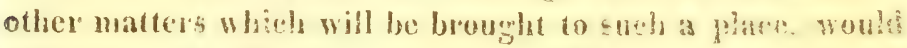

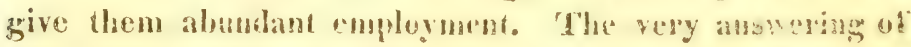
querics, the analyzing of aldeles, the explanation of enotels.

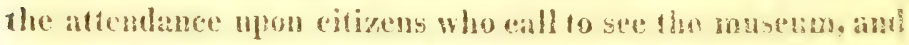
the preparation of abutrats for gement informations atre se-

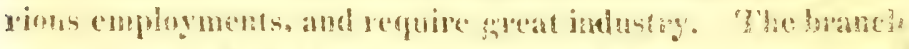

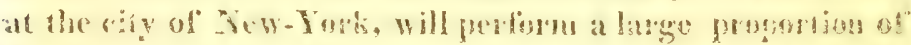

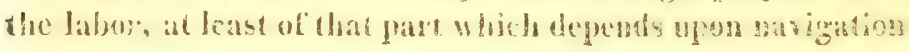
coastrise, and to toneign countries.

6. 'The danger arising from an opposition to lis" flan, fyes the farmers themselves. It seems hitherto to have been susw frected that the establishment of a lioart of Agriverture it as

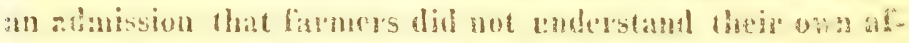

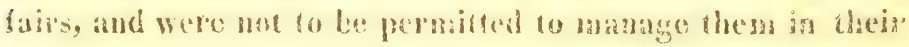
nun way. 'This is totally a mistaken itea. Where is no in-

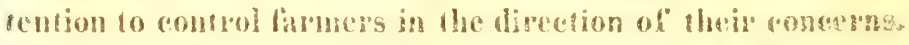

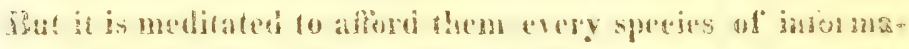

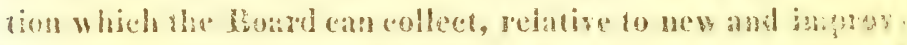

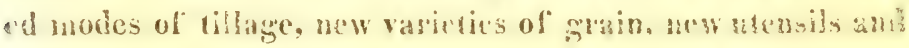

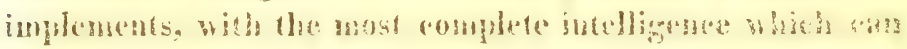
be procured about land, labsu, produce, statistias, botaby mineralogy, suils, manmes, and the assochated sulgeets. In short, the Board is expected to perform serviess highly bugortant to the public interest and honor, which are uat provided for by colleches or schouls of any hink, or in any orber

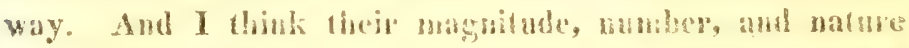
eminenty worthy of investigaton by at secisty fon intednats improvemest, countchanced by dhe legislature,

I have the pleasure to assure you of ny high estern ane legitad.

SIIL, TH MCIILE. 


\section{3 \\ JUDGE HERTELL'S LETTER:}

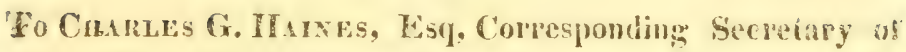
the New-York Assocition for The Promorion of Ir kirna. IMprovement.

Sir-In a conversation I recently latu with a friend on tho subject of tgrieulure, he expressed an opinien that some jdeas which 1 suggested might be wort? a publis communcation, and requested me for ligat purpose to note them in writug. This I shall attempt-and although it may be thought, from the subject of ny remartis, llas they ons?ht to fre arderessed imsuediately to the Agricultural sociesies, 1 have coneluded that their direction to an ". essociation fur the Promotion of lutinal Improzement" would not be exreptimable. 'Jhough that ansociation has particularly for its object the acruisition and diffusion of all useful inetligence conmexted wih the inland made an! navigntion of

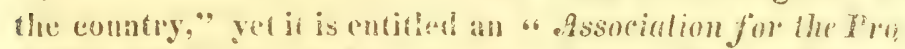
motion of Internti Improzements," and it wouhl s:mo!" strongly of incongruty will such a tille should it witides

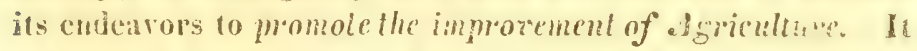
is fow the carth the wealth of naions flows. 'fo improze the vaters, cueourege and dired the intustry hy which that wealth is drawn forth and realized, falls stricely within the terans "promotion of interal improsements," and is intimately, it not inseprabibly, connected with the professed olsjects of your association. Indecd, how more chicienty couhl the interests of inland trade and naviganion be suimervede than (by prometing the improvement of atyricultate) to increase the arlicles of trate and transportalion? And bow more eflectua!ly could your association promote the interests

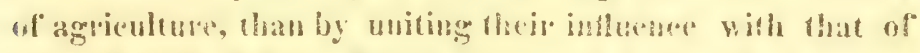

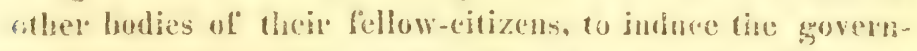
ment to pul its herd to the plongh. That the estalistament.

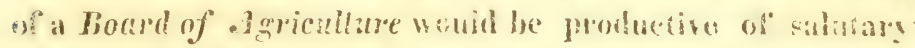

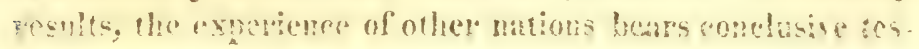


Bamony. "That the Lewisiature will on this subjeet be found

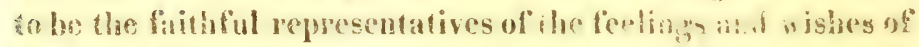
their constiuents, we are havlly germilfed to doubs. It would he nex to a libel on their wisdom and patristism. to suppose that while they estend a fostrong hand to combierere, manufectures and various departments of the ares and scienees, they should refuse to encourage and proted agricultare; the original sonree from which theme, of the abianche on which they subsist, are derived. After having exiender! Jesisiative protection to the inferest of a number of minor hofies of their constiturnts, it would inrghe a great want of eonsideration to megleet the partichlin interests of far the larsest portion of the grpeat mass of the community.

My view of the nature and objects of the association, whose organ you are. feals mo to the conclusion, that not

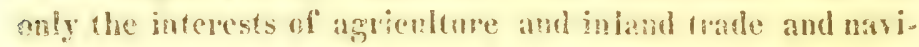
sation, bat also the promotion of the inmproment and metio-

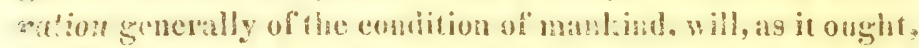
be tound ameng the vbjects of its solicitude and attention c.-.and that any measures which may terol to the attainment of these ends will meat his eordial apmobation and receise its active support.

Permit me in the first plare, finough it is not very impor. rant, to remalk, that the word anvicullure is derived from the Latio wert agricallate, which is romponded of the two

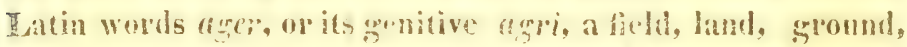
and the word cullurt, culinse, thlige. Hence, the Linglish word agriculture, which signifirs the cultivation or tillage of land: you will polbably smile and way, crery one knew this before. 'The, but then every body don't act or talk as if it was linow that from all I have seen published of the procedings of agsirulumal soretiec, am trom most pricate conversations I beas, on (what is called) the subject of agyisulture, the attention is disected mone to the improvement of the breed of

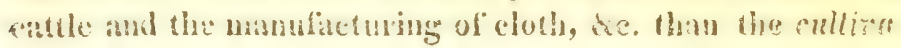




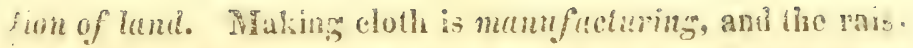
ing of caltic and iminoving the hreed is no more agrieature than the rasing of poully is sueh. These are useful ant necessary branches of rumal ceonoms. They are among the benefiedial result; of agriculiure, amb ought to be encouraged and improved with it-but they should not constitute the matu or learling ohyert of societies established to acquipe and diffuse a knuwledge of agrientural seience.

Whe science of atrienllue is a linow'dge of the means of tilling ham, and the perfection of that science is the lanowledge of the meths of ruisiag, ou a given quantity of lant. the greatev quantit! and the best qualit! of any purticular lind of food or other produe for animal subsistenec or comt. fort, at lie lase texpense, in lime, labor and money. 'This definitinancessarily imblises a knowledge of the constituent parts of the soil intendeal for tillage-the nature and quality of the seed interded to be sown, together with the mote best adinted 10 its cultivation. How else can a farmer ascertain whether or not the land is eongenial to the nature of the seed intenderl to be sown? Irow else ean he tell wherein the defieieney eas ists, or how to supply the defect? It will not he denieu that a lamentable lack of information on these sub. jects is too prevalent among our husinandmen. 'To remedy which it ought to be anoug the first objects of agrienltural instifunons 10 acyuire and disseminate a knowledge of these prinary prinejphs ol agricultural seience. The best means of doing tis may not prompily oceur. Among others which m ty be alopted lop that purpose, it woukd he well that the eonstitution and laws of the societies shouhl provide for the delivery by some intelligent member, os other enmetent. chameter, anmially of ofenes, of a discoumse cubracing these and other matters connected with the subject. Or. perhaps, it may be thought better to award a prenium to the author of the best and nost useful essay on the subject of agriculture, or any lyanels of pural ceonoiby connceter! with it. The fremium ought of hereb as to elicit pespecta 


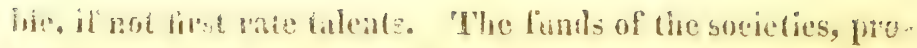
bibly, coult not be more benefieially appropriated.

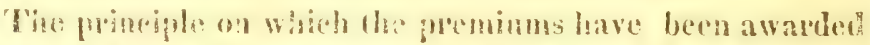

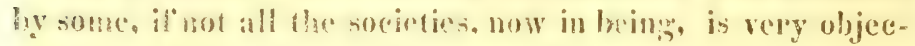
tionable, inasmuch as it does not offer an cqual chance to the eompetito:s. Il I am eorreclly advised, he who produ-

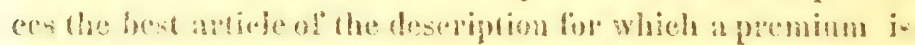

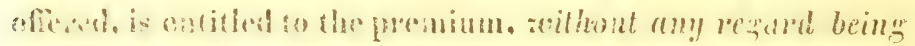
bed the thene, labor, or expense allending ils production os

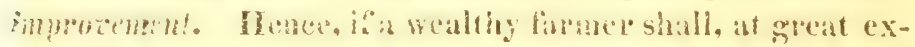

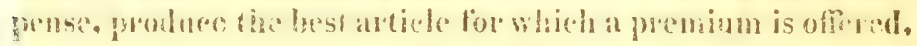
lie obtians the prenium. Now, certainly, the interest of no brath of luableconomy can be subserved by such a jroseduro. The farmer whose prudence may be greater or

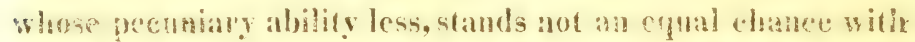
stich a cempetion. Would it not be more leneficial, as well as more just, that an account of the lime, labor, and cerpense of making this picee of cloth, of rearing or improving that animal, shombl first be asecrtained, and the premian awartict to him whose mode of mocedure shall be de'met? mas bonegicial to the interests of the farmer ant consequenty anst aroully of atoption? Of what posuble use is it to the 6.0mmuity, that an animal is reared or improved-or an ar. vicle mantiactured at an expense which could not be refumded by the proceds of the sale of the article irself, with the addition of the premium into the bargain? The eandidate for the premintu is a wealthy man, ahle and willing to make a sacritec lon the gratifiedtion of his prite and ambition: but sis example ondibt not to be followed by the great body of

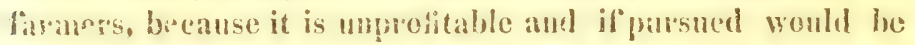
ranost. Snch a candidate sloukd mot receive a premiumto awarl it to him would he wrong, inasmuch as his examflo leals to the injury rather that the interest of rumal eenonoty.

'The stons reasoning anplies to, and the same pronciple

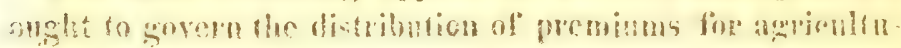




\section{8}

vai improvestents; and these shouhl be given to him acho shall, reith the least labor and exprase, raise on a giren quantity of land. the greatest quantity und the best quality of an! description of food, or other produce for animal subsistence or comfort; fir which a prestian may he offered. In this ease, particular resard being had, not only to the quantily and quality produced, but also to the labor and expense of cultiration, the premium should be gire'n to him, the raluc of rehosc erop should be greatest and best in proportion to the labor and expense, and zohose mode of culture, (which should also be a sulyject of inquiry) should be deemed best becuse most prefitable, and of course most arorthy of general adoption. Hence the fisimer who should set apart a small picee of groumd and till it at an expense which would make his manner of eulture not worth imitation, would stand no chance of obtaining a premiun;-and for this plain reason, he has done nothing which tends to promote the interest and improvement of agriculture.

'The enconiagement of pural indistry by rewading dislinguished instances of it with a premium, is well worthy of attention; and should, if possible, be earried into execution. And although the means to effect this purpose, unattended with didiculties may not readily occur, the olject should not be relinquished as unattinable without some energetic attempts to accomplish it.

I have often woudered, that while the agrieultural socicties have evineed such a laudable zeal for the improvement of the brecd of cattle, they should in no instance, or at least none that has fallen under my observation, manifest the least solicitude for the imbrorement of the ruce of Fumners. Here is a wide uncultivated field tor the exercise ef philanchropy-and it is to be regretted that it has so long remainel unoccupied. I have no difficulty in believing, that a large and respectable body of yeomanry will concur with me in the position, that for the last twenty or thirty years, great numbers of their brethen have degenerated moro 


\section{Ext-}

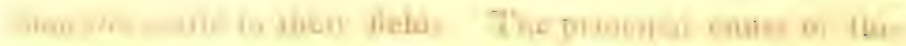

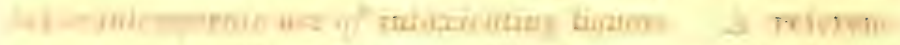

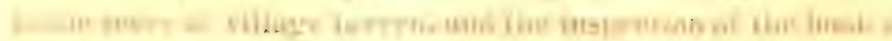

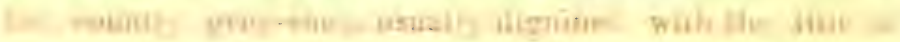

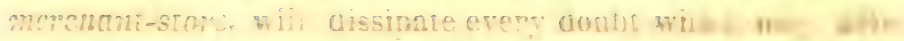

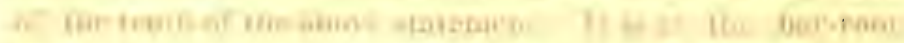

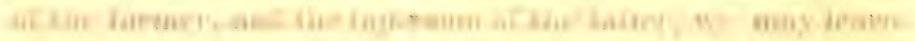

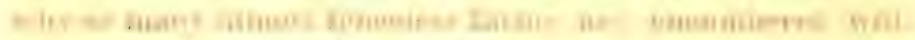

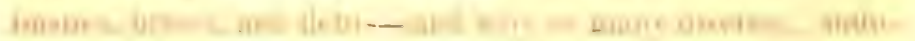

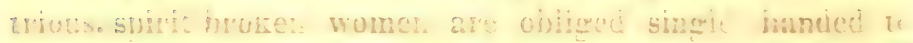

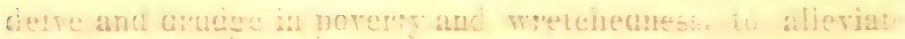

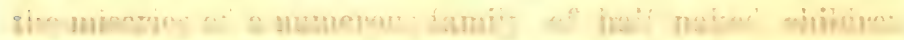

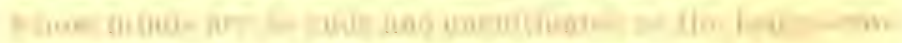

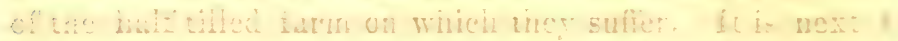

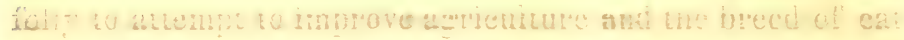

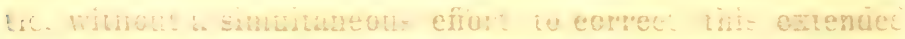

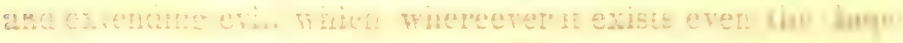

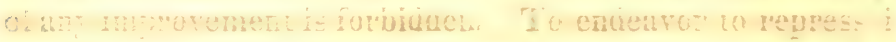

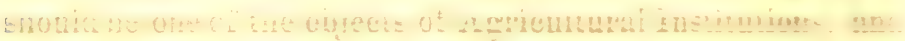

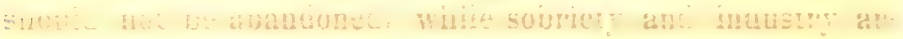

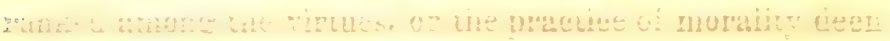

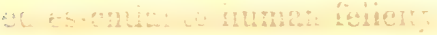

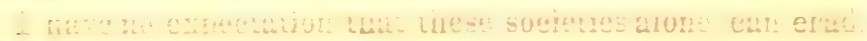

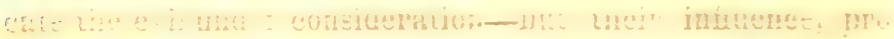

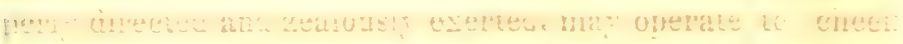

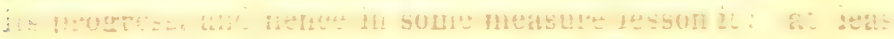

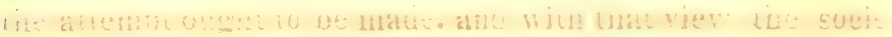

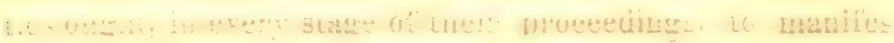

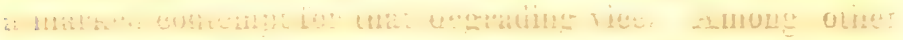

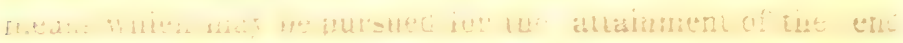

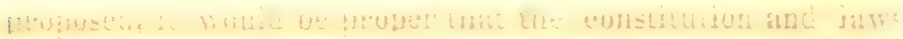

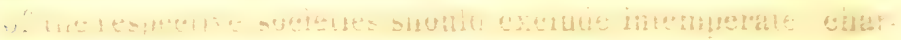

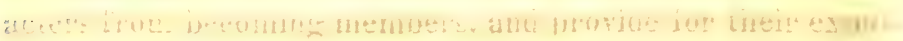

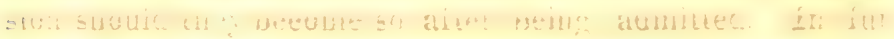

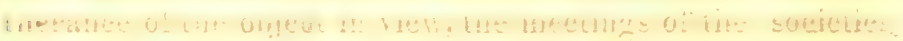

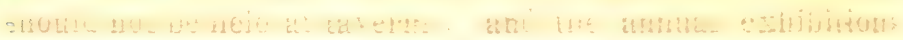




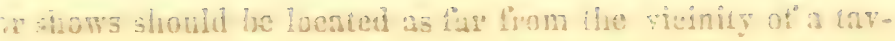

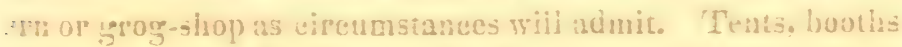

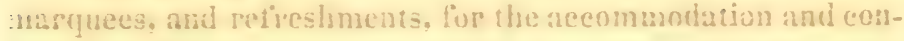
venience ot the company, misht be provided; hat intoxicating linuors of every description peremptorily interdicter.

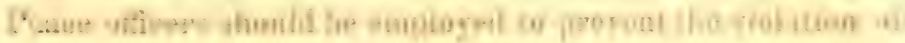
this and other salutary regulations. and particularly to re-

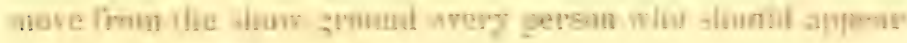
on it in a state of inebriets.

It would be loighly meritorious tor the societies [o uset

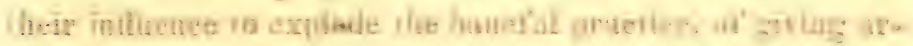
fient liquors to laborers. Should this be efitected at the ex-

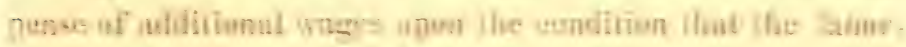
ere should forego the use of such drink while in the serwice of

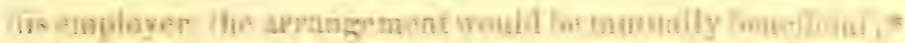

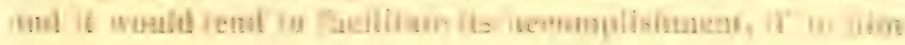
who may obtain a premium. an additional geratuity should se awalded, provided it should appear, that in the management of his fiam he has exciuded the use of spirituous linuois. I the last season witnessed on a farm lhe use of spruet beer

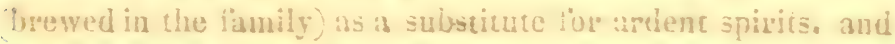
shat too without consulting the laborens on the sulbjeer, who wotwithstanding ihey were aceustomed to the use vi" the hatier, appeared not ualy reconciled to. but joleased with the - iange. Although the uniestrained use of the beer was nelmilted. the advantage in several respeets was su namilest, that the omployed teit no interest and took no trouble to astaterain whether or not the first eost of the betr was greater" sh less thun that ol the rum. "Phe little reflection bestowed कis the subject, led to a belied that the difirenee of" expense,

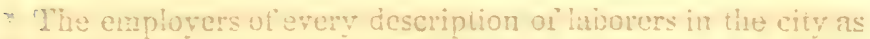
well its country, would promote their own interest, and alid the ause vi murality br matimg such a condition at part of every -onnactor services whicis are intencied to concinue sor a leneth jítime. The proprietors ol new buildings would not be amonge

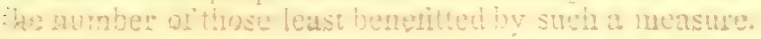




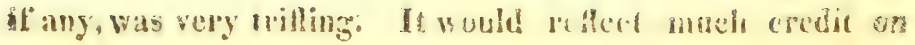
the societies should theg tondeaver to dimeoren and recommend tor general use the bust substiture fur artent spirits, as a fiold and table beverage.

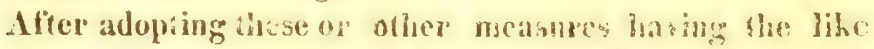

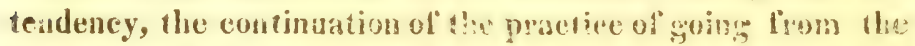
show ground to taverns, and cating stiaptuous thingers ant drinking a profusion of liquers, in houm of the sectision, would exhibit something mole than the stere tir of inconsistency. Were the efects of this proctice as inuedent as the motive which induces it, it woud rot be uljectsmahle; bue that is not the ease; it leads many to the tavera who per haps otherwise would not gro. It ollits the eqprostusily, ant? with it, the induement to induge too freety ; sub the uera.

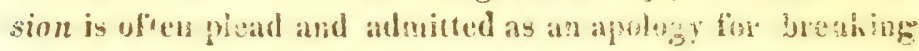
the guant to moderation. Hesiles, its infornec as an exstuple of extrayagance is rot hatmiess; some sostizy farmers, who may feel themselves neiber able nor willac to

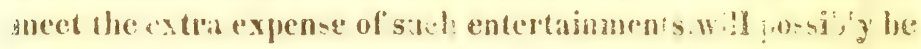

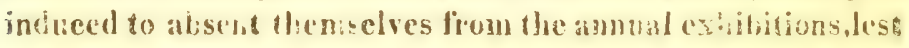
by being present and not partaking of the fenst, theis ;rydence might be mistaken for meanuess, and llesir fragabitg for niggardness, For these seasons of would hope that line societies in future would either onit the se fiasts, or exchas

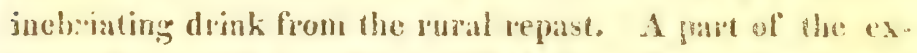
pense thus saved, could be applied towadus parthasing ats Agriculcural Library for tise use of the socich ics, an appo-

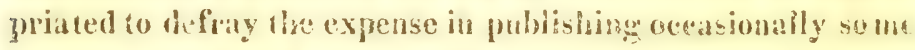

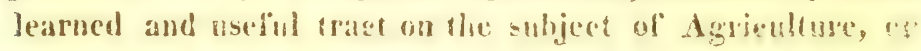
other branch of rural ecenomy.

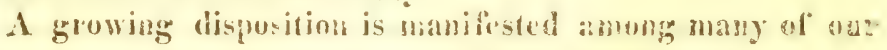
farmers, te atlopt the fastionable follies which ton much pre-

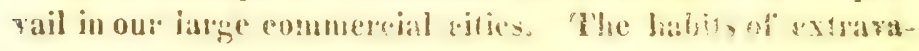

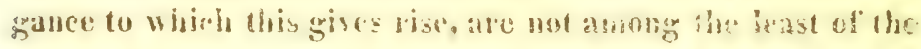
causes which lead to the impoverishment of masy. It is

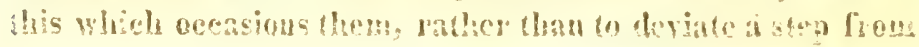


the line of fashion, to substitute foreign clothing lor flat of thei! own domestic manuficture-and this not only at extro cost, but freguently at the expense of ruinous debts. 'T'ho sucieties should endeavor to correct this crror. Indeced if mistake not, some of them do require their member's to be rall, particularly at their meetings, in Americun fabries. The cxample should be lollowed by all the societies; and ic woull tend to advance the object, if each eandidate for a preasium should receive some hono:able restimony of the approbation of the society, il he shall be clothed in clorh man ufuclured in his own fumily. It would operate as a povierful anxiliary, contal the ladies be influenced to form societics foi the encouragement and inpmovement of those branches which appertain more immediately to the female department of domestic and rural economy. What a proud spectacle for the eye of the patriot- what a problite souree of feduciation to the soul of the phitanthropist-to behold their fitit eountry women emulating each ofher io useful occupations. Rishly ardaged in the introved fabrics of their own hands,

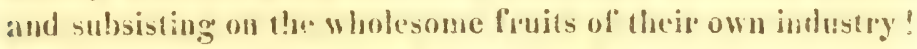
It could not then be said of them, as lamentably it may of too many of ont city belles, that " they toil not, neither do they spin, yet Solomon in all his ghlory was not arrayed libe one of these,"-who are mantaned in illeness and extravaganee by the labos's of others.

But I mint stop-I have alpealy oceupied more ground than Intemled, and perhaps have called too much. If, howerer, it has happened that I have started a solitary ifeas worth jursting, and which had not betore ocenered to goti. I shall count the rime well spent, which has been appropriated to this communication.

With much and die respect,

I have the honor 10 be, sir, your's, de.

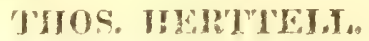

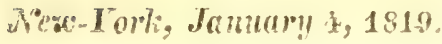




\section{MIE. EDY'S LETPER.}

\section{In Mro Charles G. Inixes.}

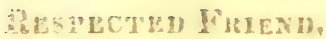

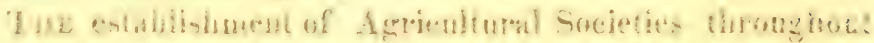

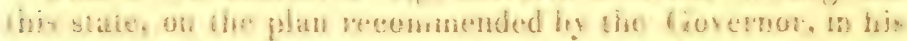

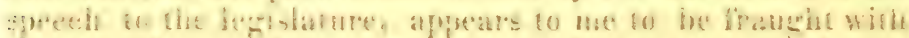

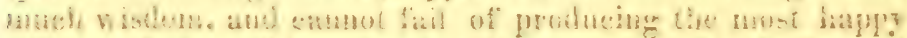

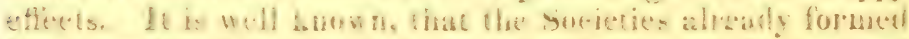
base frodued greas grod, hy stimulating esubation, and

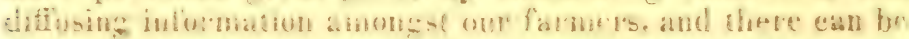
3w diube, but that as they are crereased, they will further ploduce extensive ant innomerats!e blessings.

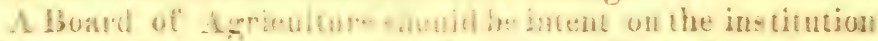

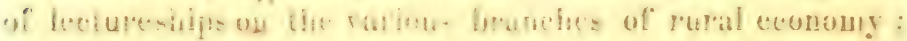

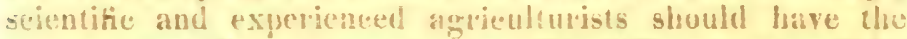

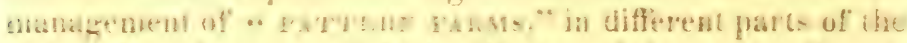
slate, where hrome might le illustrated by an intelligents

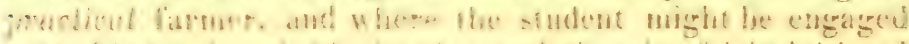

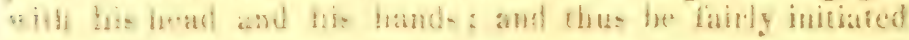
inte the thery and moretice of whatever pelates to rural and

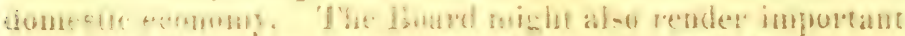

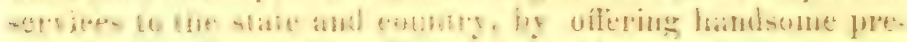

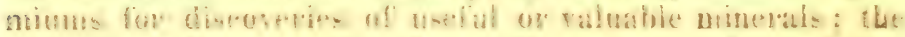

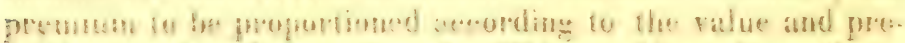

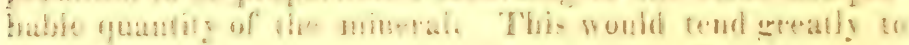
develune our resonrees, and to elicit a spoirit of nselul entermize. This plan has been gronductive of important and ralvable resules in Germany.

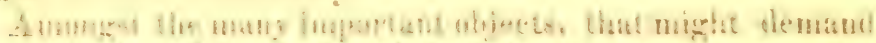

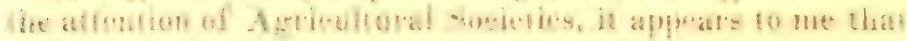
there are none which mone deserve their attention, than to Aisconrage the use of arteng spirits. Every refleting per-

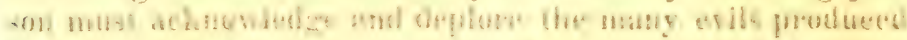
by this slow and rematin poison. It inculeates latuils of in-

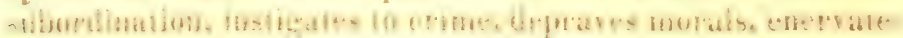
and veakens both bordy and mind, and produces idlencess; want, and misery. 'F"inese considerations induce me to be-

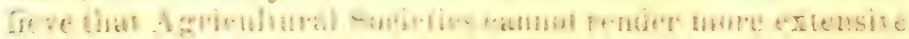
benefits tot he larming interest in the state. 1 han to use thein

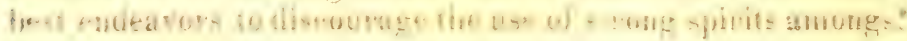

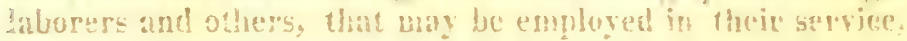




\section{3}

and particularly in harvest time. In several connties in Pennsylvania, as well as in some parts of this state, the farmers do not use any spirits in getling in their harvest. The common practice is, to take into the field about $110^{\circ}$ clock, some bread and cheese, pye, dc. and drink milk and water. cider, or small beer. Associations are formed in many towns, soiely for the purpose of diseouraging the use of spiritous liquer's, and the first resolution passed is, that evory nerber of such association will himself abstain entirely from the itse of it. Let then our Agriculiural Societies pass similar resulutioas, remenbering that example is more useful in promoting sood morals than precept. Let them also ofier handsome premiums to every farmer who will get in his harvest without giving out spirituous liquor's ; and a larger premium to every fariner who shall have got in his harvest without using strong drink, and who has prohibited the use of it, except as medicine, in his lamily for one year. Of what use to the farmer are large erops of grain, or the raising of fine eattle, unless sober habits are preserved, and the vile practice of drinking spirituous liquors avoided? Agriculture, with mpustux, is the certain road to prosperity ; whereas idleness, want, and misery, are the natural consequenees of the use of strong drink. Its extensive and alarming introducion into families, has already proved a blot upon our national eharaeter, and an injury to the American name in forejgn sountries.**

Another plan has occurred to me, which, in my opinion. might be highly useful to our farmers. Let a fund be establishet in each county, which might be called the "FARMLRS' SAVING FUND,"-The directors to receive as small

* The following statements are extracted from Seybert's Statistical Annals, founded on oficial documents. See page 460 to 464 :

1st July 1791, to 30 th September, 1792, there were in the United 2630 stilis, which made from foreign and domestic articles $5,171,564$ gallons of spirits.

In 1796 , the anmual cousumption was computed by the secretary of the treasto$3 y$ to be $10,000,000$ gallons.

In 1810 , the number of 3 tills were 14,191 and $22,977,167$ galls. from fruit \& grain.

$$
2,827,625 \text { froun molasses. }
$$

After cleducting the quantity of foreign spi-

$\left.\begin{array}{l}\text { rits exported from what was imported, } \\ \text { there semained, }\end{array}\right\}$ 7,833,093

Total, $\overline{33,677,042}$ gallons.

Computed to be about $+1-4$ gallons for each person.

In 1315, there was computed to be 15,000 stills in the United States; which emphoyed a capital of $15,000,000$ dollars: 
a sum as five dollars, and, at their diseretion, purchase puit lie stock, and the depositor's to receive an interest of five per cent, to be paid them half yearly ; the fund to be open for receiving deposits once in two wecks; the money deposited to be drawn out (when the fund is open) at the pleasure of the depositor ; but no interest should be allowed on any sum, uniess the same shall have been deposited for six months. Notes should not be issued, and no discounts made under (१ทy pretence whatezer. The directors might be annually appointed by such depositors, who had standing to their eredit dls. for — months within the year, and the d: rectors should serve gratuitonsly; all surplus profits of the fund to be divided among ail such depositors who should have _ dls, to their eredit for one year.

I cannot now further enlarge, and what has already been said may be considered merely as hints; yet I cannot refrain from adding. that amongst other important advantages that may be produced by the establishment of an Agricultural Board, and the establishment of Agricultural Societies in every county of the state, that they will serve to diffuse in the minils of our young men a taste for the pmisuits of husbani$r y$, and teach them the folly of leaving the calm and tranguil seenes of rustic life, for the bustle and great uncertainties of aties and professional pursuits.

It will eyer remain true, 'that citics rise in splen- dour and wealth, and monder into desolation and ruin, as - agriculture flourishes or declines ; and the country is either - a wilderness, a barren and trackless waste, or populous, smiling, and plenteous, in proportion to the prosperity and - suceess of its lius bandry.'

I am with mueh esteem,

Thy assured friend, THIOMAS WODY.

Nev-Yowh, 1st mo.15th, $18 \mathrm{ta}$. 
